NBER WORKING PAPER SERIES

\title{
RESIDENT NETWORKS AND FIRM TRADE
}

\author{
Lauren Cohen \\ Umit G. Gurun \\ Christopher J. Malloy \\ Working Paper 18312 \\ http://www.nber.org/papers/w18312
NATIONAL BUREAU OF ECONOMIC RESEARCH
1050 Massachusetts Avenue
Cambridge, MA 02138

August 2012

This paper previously circulated as "Channels of Influence." We are grateful for funding from the National Science Foundation. We thank Joshua Aizenman, Gennaro Bernile, Lee Branstetter, Geoffrey Booth, Bill Cready, Robert Feenstra, Fritz Foley, Rob Hansen, George Korniotis, John McLaren, Florian Peters, and seminar participants at the NBER International Trade and Investment Meeting at Stanford, Brigham Young University, Australia National University, Ozyegin University, Michigan State University, University of Alabama, University of Arizona, Baruch College, University of Amsterdam/Duisenberg School of Finance, University of Melbourne, University of Miami, University of South Florida, University of Texas at Dallas, University of Virginia, Washington University in Saint Louis, University of Mannheim, and Tulane University, for comments. The views expressed herein are those of the authors and do not necessarily reflect the views of the National Bureau of Economic Research.

NBER working papers are circulated for discussion and comment purposes. They have not been peerreviewed or been subject to the review by the NBER Board of Directors that accompanies official NBER publications.

(C) 2012 by Lauren Cohen, Umit G. Gurun, and Christopher J. Malloy. All rights reserved. Short sections of text, not to exceed two paragraphs, may be quoted without explicit permission provided that full credit, including $(\mathrm{C}$ notice, is given to the source. 
Resident Networks and Firm Trade

Lauren Cohen, Umit G. Gurun, and Christopher J. Malloy

NBER Working Paper No. 18312

August 2012, Revised April 2013

JEL No. F16,F30,G14

\begin{abstract}
$\underline{\text { ABSTRACT }}$
We demonstrate that simply by using the ethnic makeup surrounding a firm's location, we can predict, on average, which trade links are valuable for firms. Using customs and port authority data on the international shipments of all U.S. publicly-traded firms, we show that firms are significantly more likely to trade with countries that have a strong resident population near their firm headquarters. We use the formation of World War II Japanese Internment Camps to isolate exogenous shocks to local ethnic populations, and identify a causal link between local networks and firm trade links. Firms that exploit their local networks (strategic traders) see significant increases in future sales growth and profitability, and outperform other importers and exporters by 5\%-7\% per year in risk-adjusted stock returns. In sum, our results document a surprisingly large impact of immigrants' economic role as conduits of information for firms in their new countries.
\end{abstract}

Lauren Cohen

Harvard Business School

Baker Library 273

Soldiers Field

Boston, MA 02163

and NBER

lcohen@hbs.edu

Umit G. Gurun

University of Texas at Dallas

School of Management

800 W Campbell Rd. SM41

75080 Richardson, TX

umit.gurun@utdallas.edu
Christopher J. Malloy

Harvard Business School

Baker Library 277

Soldiers Field

Boston, MA 02163

and NBER

cmalloy@hbs.edu 
Firms buy and sell goods in a global marketplace. As this becomes increasingly true, understanding how firms differentially navigate this marketplace is critical to identifying which firms will ultimately succeed, and how investors should allocate capital amongst these firms. Success in this global setting depends not only on the goods or services that firms can provide, but also on the information networks that firms can access. We show that these networks have a first-order impact on the trade decisions undertaken by these firms, both in terms of imports and exports. We further explore how quickly the capital markets can separate the "strategic" importers and exporters from other firms, and show that the market appears to have a difficult time deciphering even openly observable channels.

Increasing exposure to foreign operations has been a consistent time-series trend in the United States. The Bureau of Economic Analysis's National Income and Product Accounts (NIPA) broad measure of economy-wide firm profits shows that the percentage of NIPA national profits coming from overseas has increased from roughly $21 \%$ in 2000 to $38 \%$ in 2010 (Hodge (2011)). Further, this is not a small firm phenomenon, as the entire $\mathrm{S} \& \mathrm{P} 500$ received $46 \%$ of their sales revenue from overseas in 2010, growing from only $30 \%$ ten years prior.

Although a large and growing number of public firms engage in international transactions, we still do not have a full understanding of why firms choose to trade with firms in certain countries, and how these decisions affect firm value. To shed light on this question, we exploit variation in ethnic population breakdowns across metropolitan statistical areas (MSAs) in the U.S. Specifically, we examine how local residents' ties to their home-countries can play a role in creating bilateral trade linkages and whether (and importantly which of) these trade links are value-enhancing for firms.

We do this by focusing on the import and export activity of all US publiclytraded firms for the past seventeen years. We obtain import and export data through public records that must be reported by shippers, and then made publicly available through customs and port authorities. We use this data to ask the question of whether there are strategic trade decisions that a firm can make, given the immigration patterns that result in concentrated ethnic populations close to certain firms. 
An example of our identification strategy is the following. Suppose we consider a firm located in Jersey City, New Jersey, where a common ethnicity is Indian. We first test whether this firm is more likely to trade (either import or export) with a firm in India, than a firm located in Bangor, Maine, where Indian is not a common ethnicity. We hypothesize that local ethnicities may help lower the information barriers for local companies, and thus that firms may enjoy benefits from this local advantage. In addition, ethnic make-up may also proxy for local demand for a firm's goods, which can impact optimal importing decisions. We then test the value enhancement of these links.

We find evidence that firms export more to (and import more from) countries with which they have stronger information links. We measure firm-country information networks as the share of residents in a firm's headquarter MSA that have the same ethnicity as the country to which the firm is exporting/importing (a variable we call "Connected Population"). A one standard deviation increase in connected population increases the amount the firm exports to (imports from) a country by $63 \%, t=4.71$ $(33 \%, t=2.66)$.

Next we use the formation of World War II Japanese Internment Camps to isolate exogenous shocks to local ethnic populations, and identify a causal link between local networks and firm trade links. These internment camps were established throughout the country to house Japanese and Japanese-Americans originally from the West Coast who were relocated to camps following the bombing of Pearl Harbor in 1941. The camps represented a sizable shock to the Japanese populations surrounding them, and had an enduring impact on these areas as many internees ultimately settled around these camps, having no home or work to return to when the war ended. We find that sixty years later, these internment camp locations had significantly higher Japanese populations. Further, using the instrumented value of Japanese population (with internment camp locations as an instrument), we show that this exogenously determined Japanese ethnic population density had a large and significant impact on local firm trading decisions, establishing more cleanly a causal link from surrounding ethnic population to firm-level import and export decisions. 
We also show that this increased importing (and exporting) provides a tangible benefit to the firm in terms of increased sales and increased profitability in their respective industries. For instance, "strategic exporters" (i.e., firms that export to a country that has a large connected population immediately surrounding its firm headquarters) significantly increase their future profitability (EBITDA/Assets) by over $0.9 \%$, relative to a median profitability figure of roughly $8.3 \%$.

We next go on to explore whether the market understands the value of the strategic use of information networks, and the resultant import and export decisions of firms. We find evidence that it does not. For instance, strategic exporters outperform other firms that export to the same countries but that do not have local information networks by 50 basis points per month $(t=2.15)$ in excess returns, and 57 basis points per month $(t=2.78)$ in 4 -factor abnormal returns. Importantly, this outperformance is unaffected by known risk determinants, and does not reverse, suggesting that this strategic trading behavior is truly important for fundamental firm value, but is only gradually realized by the market.

We also run a number of tests to better establish our proposed mechanism. For example, if it really is these information linkages that are increasing the amount of importing (and exporting) to the countries represented by the connected population, then we might expect that when these connections are more valuable, we should see these connections utilized more heavily. We test this idea by looking at tariff controls between the US and a given connected country for a given product. Consistent with lower (higher) tariffs increasing (decreasing) the value of the information network connection, we see significantly more strategic trading by firms (i.e., trading to the country of the connected population) where US import tariffs are lower. In addition, we show that the benefits of networks are more pronounced when importing differentiated products (products that are not traded over organized exchanges). ${ }^{1}$ These findings are consistent with the variation in the value of the network causing variation in strategic trading.

\footnotetext{
${ }^{1}$ See Rauch $(1999,2001)$ and Rauch and Trindade (2002) for evidence that network benefits in trade are strongest for differentiated products.
} 
Next, we dig deeper into the exact manner in which the information is transferred across the network, and thus profitably used by firms. While we cannot obtain the ethnic make-up of the entire employee base or management of all firms, we do collect the ethnic makeup of the firm's entire board of directors for all firms in our sample. From this data, we can identify one channel, through the board of directors, that this information network may be utilized. We first show that local ethnic population is a strong predictor of a board's ethnic make-up (i.e., if there is a larger Chinese population in a given firm's MSA, the exporting/importing firm's board is significantly more likely to have Chinese board members). We then find that when a strategic importer (exporter) has a connected board member on its firm board, it trades significantly more with the connected country. For instance, firms export $68 \%$ more than the median firm $(t=2.87)$ to countries from which they have a connected board member. Further, as is the case with strategic importers (exporters), the market does not fully understand the value of these connected board members: firms that exploit these connected board members in their trading decisions have predictable future positive abnormal stock returns.

We show that in addition to market participants not fully realizing the value of the information network for strategic importing and exporting firms, sell-side analysts make the same mistakes. Specifically, analysts are significantly less accurate in their earnings forecasts of strategic importers and exporters. Further, when their increased sales and profitability are reported at quarterly earnings announcements, strategic importers and exporters have significantly more positive earnings surprise returns. Lastly, we show that the effect of networks in international transactions is not confined to imports and exports. Using information disclosed in segment filings, we show that firms are more likely to have international sales in countries that have an ethnic presence around their firm headquarters.

The remainder of the paper is organized as follows. Section I provides a brief background and literature review. Section II describes the data, while Section III documents the impact of the connections on firm-level trade. Section IV provides evidence of a causal link using the Japanese Internment Camps of World War II. Section V establishes the returns to strategic importers and exporters that utilize these 
connected information networks, while Section VI documents other business transactions that firms engage in with countries linked by local population. Section VII concludes.

\section{Background and Literature Review}

Our research adds to a large literature analyzing the strategic entry mode choices of firms seeking to expand their businesses to overseas markets. According to Agarwal and Ramaswami (1992), these choices include exporting, joint venture, licensing, and direct investment. The underlying theme in this literature is that few companies can afford to do business in all countries at the same time; therefore firms should weigh the relative advantages of these entry modes in different regions of the world. The early marketing literature that provides normative guidelines on the process of internationalizations include Cavusgil and Nevin (1981) and Green and Allaway (1985), among others; whereas recent research on the topic focuses on the consequences of entry mode on firm operations. For example, Pan, Li, and Tse (1999) show that early entrants have significantly higher market shares and profitability than late followers. In addition, several papers investigate whether cultural proximity of foreign markets to local markets affects entry timing and mode, and find conflicting results. For example, the findings in Mitra and Golder (2002) suggest that cultural distance to domestic market is not a significant factor in entry timing; whereas Loree and Guisinger (1995) argue that it is. Our paper demonstrates that local ethnic populations around the headquarters of a firm impact the bilateral trade relations to connected countries. We also show that board members who are connected to trade partners through their nationalities provide information advantages that generate value for firms.

Our paper also links to a vast literature investigating the drivers and implications of international trade. Bernard et al. (2007) argue that, when investigating the causes and implications of international trade, the literature emphasizes several factors including comparative advantage, increasing returns to scale and consumer preference for variety, but focuses less on the firms that actually drive trade flows. They show that firms that export differ substantially from firms that solely serve the domestic market in several dimensions: across a wide range of countries and industries, exporters have been 
shown to be larger, more productive, more skill- and capital-intensive, and to pay higher wages than non-trading firms. Gould (1994) shows that immigrant ties in the United States (and Canada) play a role in increasing bilateral trade flows and conclude that immigrant ties (or links) provide knowledge of home-country markets, language, preferences, and personal contacts that have the potential to decrease trading transactions costs.

In particular, we add to the growing literature on the role that social networks and informational barriers play in impacting international trade. For example, Rauch (1999) argues that informational barriers play a key role in hampering trade, and shows that geographic proximity is more important for trade in non-homogenous (i.e., differentiated) goods. Rauch and Trindade (2002) demonstrate that ethnic Chinese networks, proxied by ethnic Chinese population shares, help increase bilateral trade, particularly for differentiated products. ${ }^{2}$ Meanwhile Chaney (2012) develops a theoretical model where firms only export to countries where they have a contact, and shows that firms use their networks of contacts to search for new trading partners; he also shows empirically that this model is consistent with the dynamics of firm-level exports in France. ${ }^{3}$ Finally, within-country evidence also highlights the importance of social networks for trade; for example, Combes, Lafourcade and Mayer (2005) demonstrate that networks facilitate trade between regions within France; Garmendia, Llano, Minondo and Requena (2012) show that social and business networks have a particularly strong impact on the extensive margin of trade in Spain; and Burchardi and Hassan (2013) show that West German regions that have closer social links with East Germany grew faster and invested more into East Germany after the German reunification. We add to this literature by isolating the effects of local ethnicities as a determinant of firm-level imports and exports to foreign trading partners.

Lastly, our research is broadly related to prior studies that analyze investors' delayed and biased reactions to information. The basic theme of this strand of

\footnotetext{
${ }^{2}$ See also Rauch (2001) and Casella and Rauch (1998) for theory and evidence on information-sharing networks among internationally dispersed ethnic minorities.

${ }^{3}$ For broader evidence on the impact of firm-level networks, see Hidalgo, Klinger, Barabási and Hausmann (2007) for evidence on how the network connectedness of products impacts country-level development, and Acemoglu, Carvalho, Ozdaglar and Tahbaz-Salehi (2012) for evidence that microeconomic idiosyncratic shocks can be transmitted through supplier-customer links and impact aggregate volatility in the economy.
} 
literature is that, if investors have limited resources and capacity to collect, interpret, and finally trade on value-relevant information, we would expect asset prices to incorporate information only gradually. One of the contributions of our paper is to highlight the importance of scrutinizing local resources in understanding asset prices. If investors pay too little attention to firms exploiting local advantages, asset prices may exhibit predictable patterns. There is an extensive literature on investors' limited attention to information. On the theoretical side, numerous studies, such as Merton (1987), Hong and Stein (1999), and Hirshleifer and Teoh (2003), argue that, in economies populated by investors subject to binding attention and resource constraints, delayed information flows can lead to expected returns that are not explained by traditional asset pricing models. Subsequent empirical studies find evidence that is largely consistent with these models' predictions. For example, Huberman and Regev (2001), Barber and Odean (2006), DellaVigna and Pollet (2006), Hou (2006), Hong, Torous, and Valkanov (2007), and Cohen and Frazzini (2008), Huang (2011), and Nguyen (2011) find that investors respond quickly to information that catches their attention (e.g., news printed on the New York Times, stocks that have had extreme returns or trading volume in the recent past, and stocks that more people follow), but tend to ignore information that is less salient yet nonetheless essential to firm values. In addition, Cohen and Lou (2011) find that investors have difficulty in incorporating industry news into conglomerates (as opposed to simple stand-alone firms in the same industry), while Cohen, Diether, and Malloy (2011) find that investors do not understand and price the predictable innovation ability of firms. These behaviors on the part of investors usually result in significant asset return predictability in financial markets. We document exactly this type of return predictability by showing that the stock market is slow to recognize the value of firms' strategic use of information networks, and the resultant import and export decisions of firms.

\section{Data}

We obtain data from several sources. Our international trade data comes from Journal of Commerce's Port Import Export Reporting Service (Piers), a subsidiary of 
UBM Global Trade. Piers collects "bill of lading" level import and export data from three major sources: U.S. Customs and Border Protection Automated Manifest System, Piers' own reporters located in 88 major ports in the U.S., and foreign partners whose national Customs authorities provide comparable data. A bill of lading is a legal document between the shipper and the carrier that outlines the type, quantity and destination of the good being carried. Our data includes standard information provided on the bill of lading and value added fields such as content (HS Code level) and the value of the cargo, both of which are estimated by Piers. We match Piers data to public firm names using shipper (for exports) and receiver (for imports) firm names using name matching algorithms. Panels A and B of Table I report the firm characteristics of public firms that import and export, and Panel $\mathrm{C}$ of Table I provides industry breakdowns of exporters and importers. Appendix Table A1 provides the analogous firm characteristics for non-importers and non-exporters. Table II reports the top 4 destination and target ports for imports and exports. ${ }^{4}$

We obtain local ethnicity data as follows. We use metropolitan statistical area (MSA)-level population data drawn from the American Communities Project (ACP), provided by Spatial Structures in the Social Sciences at Brown University. ${ }^{5}$ The Census Bureau uses a standard set of definitions of the area included in each MSA. In most cases an MSA includes both a central city (or sometimes two or more central cities) and the ring of surrounding suburbs. ACP data contain data for 331 MSAs. To match MSA to zipcodes of firm headquarters, we use Census U.S. Gazetteer files for 1990 and 2000. ${ }^{6}$

Unlike Census data, ACP data help identify the national origins of Hispanic and Asian ethnicities. ACP data allows us to disaggregate Hispanic ethnicities to 19 nations and Asian ethnicities to 7 nations. In cases where we cannot map a given nation that exists in export/imports files, we use the mapping in ethnicity to identify a nation that

\footnotetext{
${ }^{4}$ According to U.S. Customs and Border protection rules, importers may request their company name not to be disclosed on vessel manifests, and on occasion Regulations and Rulings, Privacy Branch of U.S. Customs and Border protection grant these requests for a period of two years. (https://help.cbp.gov/app/answers/detail/a_id/285/kw/19\%20CFR.\%20103.31/session/L3NpZC9Tbmxm dW5Haw\%3D\%3D). Our sample, thus, does not contain these firms. Upon inspection of our sample, we find out that almost all large firms appear to exist in our sample without a two-year consecutive break in the database, which suggests firms that constitute the majority of the import activity have not applied for custom's privacy protection throughout the sample period.

${ }^{5}$ http://www.s4.brown.edu/cen2000/data.html.

${ }^{6}$ http://www.census.gov/geo/www/gazetteer/gazette.html.
} 
is more likely to proxy for population of that nation's presence in the U.S. For example, we use Filipino population figures to proxy for Philippines, Thailand, Malaysia, Cambodia and Malaysia. Appendix Table A2 presents our country-to-MSA population mappings.

In various robustness tests, we also use coarser definitions of ethnicity drawn directly from the 1990 and 2000 U.S. Census, and which are available at the state level. The ethnicity information in the Census is based on self-identification questions in which residents choose their origin(s) or descent(s). Appendix Table A3 presents these country-to-Census ethnicity mappings.

We determine the nationality of corporate board members using biographical information provided by BoardEx of Management Diagnostics Limited, a private research company specialized in social network data on company officials of US and European public and private companies.

Finally, we also obtain Harmonized System Code (HS Code) level tariff information from the TRAINS dataset provided by the United Nations Conference on Trade and Development (UNCTAD). A typical entry in this dataset is as follows: In year 2003, U.S. applied a $4 \%$ tariff rate for Brazil nuts (HS Code 080120) to Brazil. Tariff information contains not only most favored nation (MFN) tariff rates, but also, rates agreed upon in various preferential regimes including regional trade agreements (RTA), preferential trade agreements (PTA) and bilateral agreements. If tariff data is missing for a particular importing country in a particular year for a given HS code, we use the most recent values as major tariff changes take place very infrequently.

\section{The Impact of Connections on Firm-Level Trade}

\section{A. Import and Export Decisions of Firms}

We first test the hypothesis that firms export more to (and import more from) countries with which they have stronger information links. We measure firm-country information networks as the share of residents surrounding a firm's headquarters that have the same ethnicity as the country to which the firm is exporting/importing (a variable we call "Connected Population"), where we use the fine measure of 
Metropolitan Statistical Areas (MSAs) to define surrounding area (with an analogous state-level measure included in Appendix Table A4). As joint location can be influenced by many factors, Section III can be seen as documenting the base relationship between surrounding ethnicities and firm trade decisions, while we establish a cleaner causal relationship in Section IV.

The dependent variable in our tests is a firm's import/export behavior in a given year. Specifically, for each firm in each year we compute its "Export Ratio" as the total amount that a given firm exports to a destination country in a given year scaled by the total amount of exports by the firm in that year $\left(E_{\text {ict }} / \operatorname{Sum}\left(E_{i t}\right)\right) .^{7}$ We define "Import Ratio" analogously for imports. All export and import figures are converted to U.S. dollars, and represent the dollar value of exports and imports by a given firm.

In Table III we present results from a panel regression of firm-level export and import behavior on firm-country information networks, plus a host of fixed effects. The unit of observation in these regressions is firm-country-year, and all standard errors are clustered at the year level to broadly allow for any correlations that impact all firms over a given year (i.e., tariff changes, conflicts, shipping blockages, etc.). ${ }^{8}$ Panel A presents the results with Export Ratio as the dependent variable; each specification shows that Connected Population $\left(\mathrm{CP}_{\mathrm{ct}}\right)$ is a positive and significant predictor of a firm's country-level export share. We add fixed effects across specifications in Columns 1-4 for firm, year, MSA, country, firm x year, and MSA x country, with the coefficient on Connected Population remaining large and significant. In terms of magnitude, the coefficient of $0.039(t=4.71)$ on $\mathrm{CP}_{\mathrm{ct}}$ in Column 2 implies that for a one-standard deviation increase in $\mathrm{CP}_{\mathrm{ct}}$, a firm's Export Ratio increases by $1.30 \%$; relative to median Export Ratio 2.06\%, this implies a $63 \%$ increase. In Column 5, we also investigate the extensive margin of exporting and find that a firm's connected population around its corporate headquarters is a significant predictor of a firm's likelihood of exporting to a

\footnotetext{
${ }^{7}$ If we instead scale by exports of all U.S. public firms to the given country in the same year, we also find strong and significant results. The magnitudes are actually quite close, on average roughly $4-7 \%$ larger than in Table III, while each analogous specification is highly statistically significant $(p<0.01)$.

${ }^{8}$ We have run these analyses also clustering standard errors at the firm level, MSA level, and state level, which give comparable standard errors, and all results remain significant.
} 
given country. ${ }^{9}$ A one-standard deviation increase in $\mathrm{CP}_{\mathrm{ct}}$ increases the likelihood of exporting to a given country by $1.46 \%$. Compared to the mean export extensive margin of $0.38 \%$, this implies a large economic impact in magnitude.

Panel B presents the identical set of tests using Import Ratio as the dependent variable. As in the export tests, we find that ethnic information links are strong positive predictors of firm-level import behavior. The magnitude of this effect is again large: the coefficient of $0.032(t=2.70)$ on $\mathrm{CP}_{\mathrm{ct}}$ in Column 2 implies that for a onestandard deviation increase in $\mathrm{CP}_{\mathrm{ct}}$, a firm's Import Ratio increases by $1.05 \%$, which this translates into a 34\% increase (when compared to the median Import Ratio of $3.14 \%$ ). Furthermore, Column 5 implies that a one-standard deviation increase in $\mathrm{CP}_{\mathrm{ct}}$ increases the likelihood of importing from a given country by $1.85 \%$. Compared to the mean import probability of $3.22 \%$, this again implies a significant impact.

\section{A.1 Connected Board Members and Trade Decisions}

We next explore in more depth the exact manner in which the information is transferred across the network. While we cannot obtain the ethnic make-up of the entire employee base or management of all firms, we do collect the ethnic makeup of the firm's entire board of directors for all firms in our sample. From this data, we can identify one channel, through the board of directors, that this information network may be utilized. These directors are involved with important firm-level decisions, such as the establishment and continuation of export and import relationships with foreign firms (Gevurtz (2004)). We first show that local ethnic population is a strong predictor of a board's ethnic make-up (i.e., if there is a larger Chinese population in a given MSA, the exporting/importing firm's board is significantly more likely to have Chinese board members). Specifically, the correlation between the percentage population from a certain country and having that country represented on the board of a firm in that MSA is highly significant $(\rho=0.20, \mathrm{p}<0.01)$.

\footnotetext{
${ }^{9}$ These tests are constructed similarly to those in the first four columns of Table III, except that here we include all possible trade partners in the world (whether or not the firm traded with these nations or not); if the firm did trade with this country, the left-hand size variable is a dummy variable set equal to one, and if not, the left-hand side variable is set to zero).
} 
The variable we use to capture the impact of this ethnic link seen through the board of directors is Connected Board Member, which is a categorical variable equal to 1 if the firm has board member whose nationality is the same as that to which the firm is importing (exporting), and 0 otherwise. From Panel A and Panel B of Table III, this connected board measure is a large and significant determinant of firms' trading decisions. For instance, in Column 4 of Panel A, the coefficient estimate of 0.014 $(t=2.87)$ implies that a firm exports $68 \%$ more to countries from which it has a connected board member.

\section{B. Tariff and Differentiated Product Analysis}

In our next set of tests, we exploit shocks to the value of firm-country links. In particular, we use product-level data on imports for the firms in our sample, and identify situations where country-specific tariffs set by the US on types of goods are higher or lower. Thus our tests are similar to those in Table III, except that they are now run at the product level, and hence the unit of observation in the regressions is the firm-product-country-year. In addition, we include new variables designed to measure the impact of tariffs, for example a variable called "Tariff" which is equal to the US import tariff on the given product imported from the given country in the given year. These tariffs are gathered from the TRAINS dataset maintained by the United Nations Conference on Trade and Development (UNCTAD). We also include the interaction term between tariff cuts and firm-country information links (Connected Population*Tariff). Since US tariffs only bind for imports, we only run these tests using the Import Ratio as the dependent variable.

Table IV presents the results of these tests. Specifically, we run panel regressions of import ratios on firm-country information links, plus the tariff variables described above, along with various fixed effects including firm-, year-, and product-fixed effects. From Column 3, the coefficient on the interaction term (Connected Population*Tariff), which is negative and significant $(=-0.0022, \quad t=4.49)$, suggests that Connected Population has only roughly $20 \%$ the impact when tariffs are one standard deviation larger to the country. In other words, precisely when it is more costly to utilize the 
advantages of the Connected Population, Connected Population has a significantly smaller effect on import decisions of firms.

In the last two columns, we also investigate whether the effects of networks are more pronounced for certain types of products. For this purpose, we use the differentiated versus homogenous product classification of Rauch (1999). Homogenous products are those that one can obtain from organized exchanges. ${ }^{10}$ Rauch (1999) provides a theory that the immigrant-link effect on trade should be greatest for differentiated products, and smallest for homogeneous products traded on organized exchanges. Column 5 shows that the network effects we identify are indeed significantly more pronounced when importing differentiated products as opposed to homogenous products; however, we find no significant differential effect across product types for exports.

Taken as a whole, the results in this section are consistent with firms exporting (importing) significantly more to (from) countries with which they have stronger information links. Both effects are economically large, and consistent with firms exploiting their information networks when making their trade decisions. Further, at times when particular products are more attractive (such as after a tariff cut), the impact of these information linkages on product-level import behavior is more pronounced.

\section{Japanese Internment Camps of World War II}

Although we have shown a strong correlation between surrounding ethnic population and trade activity, nothing up to this point has addressed the direct causal impact of ethnic population on import/export activity. This relationship could be driven by a number of factors and not necessarily by a direct causal channel from ethnic population to trade. For instance, it could be that groups of firms are simply bringing

\footnotetext{
${ }^{10}$ We thank James Rauch for providing product classifications (http://weber.ucsd.edu/ jrauch/research_international_trade.html). We use the conversion tables maintained at United Nations to map these Standard International Trade Classification (SITC Rev. 2) based classification to HS Codes used in vessel manifests (http://unstats.un.org/unsd/trade/conversions/HS\%20Correlation\%20and\%20Conversion\%20tables.htm).
} 
in the foreign population when they plan to import/export to the resultant country. It may also be that some outside factor is causing both people of a certain ethnicity, and firms planning to trade with their home country, to locate in the same location, but the ethnic population themselves have no direct impact on trade. One example of this is geographic distance. For instance, it is both easiest for Vietnamese immigrants to reach California (as opposed to New York), along with it being cheaper for California firms to ship goods to and from Vietnam (relative to a New York firm). Although we control for this particular channel in Table III, other types of these common attributes could drive both ethnic population and trade, but have no causal path.

In order to establish causality, we need exogenous variation, such as exogenously "dropping" firms in random locations, or exogenously "dropping" ethnic populations in random locations, and then running our tests to see if these exogenously matched firmsurrounding ethnicities product the same impact. We run exactly this latter experiment by examining the Japanese Internment Camps of World War II.

\section{A. Japanese Internment Camps, Current Population, and Trade}

The Japanese Internment Camps were part of a program by the United States government to relocate and intern Japanese and Japanese-Americans following the attack on Pearl Harbor in Hawaii. The relocation stemmed from a worry ${ }^{11}$ that if there was an invasion by Japan, these citizens might work against US interests. The camps were constructed in 1942, and held nearly 115,000 Japanese and Japanese-Americans. The internment camps were distributed unevenly throughout the US, as shown in the Figure I, with peak populations shown in the accompanying table. An additional important aspect of the relocations is that they represented substantial increases in terms of Japanese-origin population for states of the relocation camps. To illustrate this, we collected data from the 1940 US Census for the states that had internment camps, and show this in Figure 1. From this data, for instance, Arkansas had only 3 people of Japanese descent in the 1940 census, compared to roughly 17,000 Japanese

\footnotetext{
${ }^{11}$ The order to create the camps and authorize the relocations themselves was Executive Order 9066, signed into law on February 19, 1942.
} 
and Japanese Americans relocated to the internment camps. Accordingly, the number of Japanese that were interned in these camps represented a substantive shock to the total Japanese population in these states.

The camps were fully evacuated by 1946 (Burton et. al (2000)). However, prior to internment, many of these internees had to quickly sell their homes and other assets before leaving, as they were not sure what would happen to them, nor how long they were to be interned (Okamoto (2000)). Added to this, many internees that did try to return to their former West Coast home cities faced acts of violence and discrimination (Ina et al. (1999)). Both of these resulted in many internees resettling in the regions surrounding their internment camps (Ina et al. (1999)). Our identification comes from these internees who decide to remain, settle, and form communities in the regions around the internment camps.

However, we need to formally establish the fact that the internees who decided to stay do materially impact the population of Japanese origin in the decades following, and particularly during our sample period. This first-stage regression is shown in Panel A of Table V. It is simply testing whether the states that housed internment camps see a larger percentage of Japanese origin population today. The dependent variable is thus Connected Population from Table III, the percentage of the population of Japanese origin. The independent variable Japanese Internment is then a categorical variable indicating whether there was an Internment Camp in that state or not. In this analysis we are restricting the sample solely to connections to Japan, and so are estimating the varying connections to Japan given the Japanese Internment relocation camp locations.

From Panel A of Table V, we see that MSAs in states that had a Japanese Internment camp during World War II have a significantly higher fraction of Japanese origin connected population today. Columns 1 and 2 run the test on the sample of firms that export to Japan, while Columns 3 and 4 run the test on the sample of firms that import from Japan. All four columns deliver this same message. Columns 2 and 4 include an additional control of Immigration from Asia, which measures the immigration growth from all other Asian ethnicities listed in the US Census (other than Japanese) 
from 1940 - 1990 (before the internment to the beginning of our sample period). ${ }^{12}$ The idea of including this control is that immigration may have been growing in general in all states over this time period, and for some reason these internment states may have been the recipient of a shock of immigration. From Column 2, the coefficient of 0.0079 $(t=3.41)$ on Japanese Internment implies an over 3.5 times larger current Japanese population in areas surrounding Japanese Internment Camps of World War II relative to areas without. The Column 4 coefficient of $0.0098(t=4.65)$ on Japanese Internment implies a difference of over 4 times as large.

This provides strong evidence for the first stage of the instrumental variable test. For the second stage, we then regress trade activity today on this instrumented value of connected population to see its impact. In other words, we examine the impact on trade activity of solely the part of the Japanese connected population today that was determined by having (vs. not having) a Japanese Internment Camp in the surrounding area in World War II. These second stage regressions are shown in Panel B of Table V. All four columns show that this instrumented connected population has a large and significant impact on trade activity today. For instance, the coefficient in Column 2 of $11.670(t=2.84)$ implies that a one standard deviation increase in connected population increases the Export Ratio by $65 \%$ (from $22.5 \%$ to $37.2 \%$ of exports to Japan). For imports, the estimated coefficient in Column 4 of $7.992(t=3.62)$ implies that a one standard deviation increase in connected population increases the Import Ratio by $62 \%$ (from $21.9 \%$ to $35.5 \%$ of imports from Japan). These are similar in magnitude to the estimates from Table III. ${ }^{13}$

\section{B. Placebo Tests and Corroborating Evidence}

The Japanese Internment Camps of World War II appear to have lasting impacts on their surrounding areas. We explore these impacts further with a number of

\footnotetext{
${ }^{12}$ For an image copy of the full 1940 census instructions, see http://www.lib.ncsu.edu/guides/popcensus/images/1940enu.pdf.

${ }^{13}$ These Table $\mathrm{V}$ tests are robust to many specifications. For instance, we can include fixed effects for those states along the western coast of the US that are closest to Japan. Our estimates are nearly unchanged in magnitude and significance. In addition, we have clustered by year which produces slightly smaller standard errors (so larger t-statistics) for both stages of the analysis than those that we report clustered by state.
} 
corroborating pieces of evidence. First, many cities in the states housing the Internment Camps to this day have organization chapters that serve former internees and their children (Ina et al. (1999)). Second, to get another measure of long-lasting ties to Japan, we gather the list of all sister cities to United States cities. ${ }^{14}$ In Panel C of Table $\mathrm{V}$, we then run a simple regression of number of sister cities in Japan of a given state on Japanese Internment (whether or not the state had an internment camp during WWII). We collapse this analysis at the state level, and use the 44 states that have reported census data on ethnicity going back to 1940, so there are 44 observations in this regression. From Panel $\mathrm{C}$ of Table V, while the average state without an internment camp had less than 3 sister cities in Japan, those with an internment camp had three times as many, 9 Japanese sister cities. Despite the small sample of only 44 states, this large difference of 6.22 cities is significant $(t=2.10)$.

We then run a placebo test for our main analysis. If the areas that the camps were located in were also centers of attraction for immigration that happened after WWII, then it is possible that our instrument is essentially capturing the variation in growth of immigration across states, rather than the presence of Japanese population caused by the internment camps. However, if our Japanese Internment variable is truly capturing something unique about the lasting link solely to Japan, then we should only see it having a predictive ability for Japanese immigration. To run this test, we compare the ability of our Japanese Internment variable to predict Japanese linked population connections compared to those of all other Asian ethnicities reported in the census other than Japanese (specifically, as coded by the census: Korean, Chinese, Hindu and Filipino). Again, we collapse measures of the Connected Population (to both Japan and other parts of Asia) at the state level, so have 44 observations in these tests.

From the second column of Table V Panel C, when we collapse our analysis at the state level we continue to see a strong and significant relationship between Japanese Internment Camps and Japanese linked populations decades later. However, when we run the placebo-test looking at the same link for other Asian ethnicities, we see a small and statistically zero impact of having the Japanese Internment Camps during WWII.

${ }^{14}$ This data was gathered from http://www.sister-cities.org/. 
As a final way to highlight the unique importance of the Japanese Internment Camps in determining connected populations, we run a specification including other Asian ethnicities' population in a state as a control variable to finely control for any reason why immigration may have grown from Asia to any given particular state. The fourth column of Table V, Panel C, shows these results. While the contemporaneous Japanese connected population and other Asian ethnicities' connected populations are (not surprisingly) correlated, the Japanese Internment Camps represent a source of Japanese connections completely orthogonal to this former relationship (as the magnitude and significance of the Japanese Internment variable is quite similar in magnitude and significance to Column 2).

\section{Firms Founded before World War II}

As a last remaining concern, one might that think that firms' location choices may still be impacted by the population ethnicities it observes. So, although the Japanese origin citizens are exogenously assigned, firms who plan to trade with Japan may be responding by deciding to establish themselves around Japanese population centers. In a sense, this is in line with our explanation, as firms' trade decisions are still impacted by the population ethnicity, and so given that part of that ethnic profile was exogenously determined, it would simply mean that even firm establishment locations are impacted by the same population ethnicities.

However, to more cleanly measure the impact of the exogenous population ethnicity on firm decisions, we examine only firms that were founded before the Japanese Internment Camps populations existed. ${ }^{15}$ We thus restrict solely to firms founded before 1946, the year in which the Japanese Internment Camps dissolved and had released all internees. Although this obviously reduces the sample size, the same results from Table $\mathrm{V}$ obtain. Namely, the first stage regressions still have large and significant coefficients on the impact of Japanese Internment Camps on Japanese

\footnotetext{
${ }^{15}$ We obtain firm founding date data from the Field-Ritter Founding Date Dataset available at: http://bear.warrington.ufl.edu/ritter/FoundingDates.htm, as used in Field and Karpoff (2002) and Loughran and Ritter (2004).
} 
population today, with the second stage coefficients on instrumented Connected Population also being large and significant (despite the reduced sample size).

In summary, the main Japanese Internment Camp tests, the corroborating evidence, and the placebo tests all deliver a consistent message: namely that the Japanese Internment Camps were indeed an exogenously "dropped" population, and that this exogenously dropped population did indeed have a causal impact on trade flows to Japan.

\section{Strategic Traders and the Returns to Information Networks}

In this section we build on the results above, and examine to what extent firms benefit from using their firm-country networks in their import and export decisions. For example, one could imagine firms overweighting certain countries in their import and export decisions due to a form of familiarity bias; alternatively one might expect firms to tilt their trading focus as a result of superior private information about certain countries.

We try to disentangle these two possibilities by examining the future outcomes of firms that exploit their firm-country linkages in their trading decisions. We term those firms that exhibit strong links between their ethnic environment and their major trading partners as "Strategic Traders." The essence of our approach is to isolate firms that export primarily to countries where there is a match between the destination country's ethnicity and the firm's headquarter location's ethnic composition. Since each firm can have an export/import relationship with several different countries over the same time period, a goal of our approach is to identify firms that choose their export countries in line with their various potential information linkages. Because some firms will trade with only 1 country across a given time period, and others will trade with many, the number of possible "informed" or "linked" shipments each month will vary by firm. As a result, we first create buy/sell signals (to denote "linked" versus "non-linked" shipments) based on a firm's export amount in a given month, its destination country, and the match between the destination country's ethnicity and the firm's headquarter MSA's (metropolitan statistical area) ethnic composition. We employ MSA-level 
ethnicity shares, and match these to destination countries as shown in Appendix Table A2. In every year for each MSA, we compute the share of each ethnicity that resides in each MSA. We then rank the share of each ethnicity across all MSAs in the US. The buy signal equals one if (i) a firm's share of total industry exports to a given country in a given month is ranked in the top $3,{ }^{16}$ and (ii) the firm is located in an MSA where the MSA's ethnicity share across all MSAs in the US is ranked in the top 3. The sell signal equals one if (i) a firm's share of total industry exports to a given country is ranked in the top 3, but (ii) the firm is * not* located in an MSA where the MSA's ethnicity share across all MSAs in the US is ranked in the top 3. For the real outcomes tests below, we define a firm as a "Strategic Exporter" if the firm has at least one buy signal for any of its exports in a given year; meanwhile a firm is defined as a "Non-Strategic Exporter" if it has zero buy signals in a given year, and has at least one sell signal.

A simple example helps to clarify our approach. Consider two firms: A and B. Firm A is located in an MSA (e.g., Jersey City, New Jersey) where the share of Indian residents is in the top 3 across all MSAs. Firm A exports a significant amount (relative to its industry) in a given month to India. By contrast, Firm B is located in a different MSA (e.g., Bangor, Maine) where the share of Indians is not in the top 3 across all MSAs (Bangor is ranked $156^{\text {th }}$ in population share of Indians across all MSAs), and yet Firm B also exports a significant amount (again relative to its industry) in a given month to India. Thus although Firm A and Firm B are engaging in identical behavior (exporting a significant amount to India in a given month), Firm A will be classified as a "Strategic Exporter," and Firm B will be classified as a "Non-Strategic Exporter."

Using this classification procedure, we then examine the future real outcomes and future stock returns of these strategic and non-strategic traders.

\footnotetext{
${ }^{16}$ Our results are similar if we measure export intensity within-firm (e.g., using the "Top 3" export amounts within a given firm in a given month), or if we use industry export decile breakpoints (top decile) rather than a "Top 3" ranking. Finally, our results are also virtually identical if we use firm-level export shares to a given industry rather than absolute amounts. For example, Firm A could export $\$ 100$ worth of materials to Italy and $\$ 100$ to Germany, while Firm could export $\$ 10$ worth to Italy and $\$ 5$ to Germany; in absolute terms Firm A exports more, but its within-firm share (50\%) would be smaller than Firm B's $(66 \%)$ within-firm share; our results are similar for both of these ranking measures.
} 


\section{A. Future Real Outcomes of Strategic Traders}

We first investigate whether strategic traders on average achieve superior real outcomes in the future, relative to their non-strategic counterparts. To do so, we run panel regressions of future sales and future profitability on lagged strategic trading activity. The dependent variables are: 1 ) future sales (in year $t+1$ ) divided by lagged assets (in year $t$ ); and 2) ROA (defined as future EBITDA in year $t+1$ divided by lagged assets in year $t$ ). We include a series of control variables, including size (log of market capitalization), B/M (log of the book-to-market ratio), leverage (long-term debt in year $t$ divided by lagged assets in year $t$ ), and cash (future cash in year $t+1$ divided by lagged assets in year $t$ ). We also include fixed effects for time (year) and firm in all of these regressions.

Table VI presents the results of these real outcome tests. Specifically, Column 1 shows that strategic exporters achieve higher sales in the future. The coefficient of $0.026(t=2.89)$ implies that relative to a median sales-to-lagged assets figure of 0.56 , strategic exporters achieve almost 5\% higher future sales. Meanwhile the coefficient indicator variable for non-strategic exporters is close to zero, and insignificant. In terms of future profitability (EBITDA/Assets), Column 3 indicates that strategic importers achieve significantly higher profitability (coefficient $=0.009, t=2.05$ ); relative to a median profitability of 0.083 , strategic exporters experience roughly an $11 \%$ increase in profitability. At the same time, non-strategic exporters show a statistically significant decline in profitability (coefficient $=-0.006, t=2.95$ ) in the year after their non-strategic export decisions, on the order of $-7 \%$. Columns 5-8 repeat the same tests for imports, and reveal that strategic importers earn significantly higher sales (coefficient $=0.019$, $t=3.24$ ), but do not achieve significantly higher profitability. Non-strategic importers show no increases in sales or profitability in the future. Collectively, the results in Table VI suggest that strategic traders do receive real, tangible benefits from their firmcountry networks in their import and export decisions, as strategic traders achieve higher sales (for both importers and exporters) and higher profitability (for exporters) relative to non-strategic traders. 


\section{B. Future Stock Returns of Strategic Traders}

Next we examine the future stock returns of strategic traders versus non-strategic traders. The goal of these tests is to determine if the market properly prices the real outcome benefits that strategic traders receive from their import and export decisions. We begin with exports, and construct buy/sell signals for all export decisions as in the real outcome tests from Table VI; however, since returns are available more finely (monthly, unlike accounting variables), we now define a firm as strategic exporter if the firm has at least one buy signal for any of its exports in a given month. A firm is defined as a non-strategic exporter if it has zero buy signals in a given month, and has at least one sell signal. Each month we construct calendar-time portfolios that buy stocks of strategic exporters and sell non-strategic exporters. Portfolios are rebalanced monthly, and stocks are held for one month. Importantly, all information used to create the portfolio at month $(t)$ was publicly available in month $(t-1)$, so the market could have updated to this information in month $(t-1)$. Alternatively, any investor could have traded exactly as our portfolios using this publicly available information to obtain these portfolio returns.

Table VII shows the results. The first row of each panel presents excess returns (raw returns minus the risk-free rate), the second row shows DGTW-adjusted returns, the third row shows CAPM alphas, the fourth row shows Fama-French 3-factor alphas, and the fifth row shows Carhart 4-factor alphas. In Panel B, we replicate the calendar time portfolio approach from Panel A for our imports sample.

Panel A of Table $\mathrm{V}$ indicates that a portfolio strategy that buys strategic exporters and shorts non-strategic exporters as described above earns large abnormal returns. The value-weight excess returns on this long-short portfolio equals 50 basis points per month $(t=2.15)$; the corresponding value-weight four-factor alpha is 57 basis points per month $(t=2.78)$. The long-short DGTW-adjusted returns are 39 basis points per month $(t=2.23) .{ }^{17}$ These estimates translate to annual abnormal returns of roughly

\footnotetext{
${ }^{17}$ As we weaken the strength of the ethnic connection, for example by using a Top 5/Top5 cutoff or a Top 10/Top 10 cutoff (rather than a Top 3/Top 3 cutoff as described in Section V.A) in order to define our strategic importers, the results are weaker, as we would expect. For example, the DGTW-adjusted returns on the long-short portfolio are 37 basis points per month $(t=1.88)$ using a Top $5 /$ Top 5 cutoff, and 29 basis points per month $(t=1.64)$ using a Top 10/Top 10 cutoff.
} 
5-7\% per year. Most of the return spread comes from the long side of the portfolio; for example, the long portfolio return earns a 4 -factor alpha of 53 basis points $(t=2.82)$, while the short portfolio alpha is small and insignificant. ${ }^{18}$ Panel B reveals similar, but statistically weaker, results for importers. For example, the value-weight excess returns on the imports long-short portfolio equals 45 basis points per month $(t=1.75)$; the corresponding value-weight four-factor alpha is 38 basis points per month $(t=1.45)$, and the long-short DGTW-adjusted returns are 45 basis points per month $(t=1.92)$.

Collectively, the calendar-time portfolio results in Table VII indicate that strategic traders (particularly strategic exporters) earn substantial abnormal returns relative to their non-strategic counterparts. This result suggests that these firms are not overweighting certain countries in their import and export decisions due to a form of familiarity bias, but rather as a result of superior private information about certain countries. Further, the market does not seem to recognize the advantage of these types of strategic export/import decisions by firms, as the mimicking portfolios in Table VII produce economically meaningful abnormal returns.

\section{Connected Board Members and Future Returns}

In this section, similar to Section B, we test whether the market realizes the potentially positive impact to firm value of import and export decisions made by firms who have the strategic link to their trading partners of a connected board member. The measure we use for this is Pct of Board Strategically Connected, which is simply the percentage of the board that is from countries to which the firm is actively engaged in importing or exporting. In Table VIII, we run Fama-MacBeth cross-sectional predictive regressions of future returns with this variable, controlling for other known return

\footnotetext{
${ }^{18}$ As described in Section V.A, the short portfolio here includes the set of non-strategic exporters, i.e., firms that are located in regions without a strong ethnic link to a particular country, and yet choose to export to that country anyway. We have also run tests where the short portfolio includes the subset of non-strategic exporters who have a strong ethnic tie to at least one particular country, and yet choose to export to a different country. These long-short portfolio returns are even larger in magnitude, and the short portfolio returns are more negative, but the long-short portfolios contain fewer stocks, and hence these returns are noisier and statistically insignificant. For example, the long-short CAPM, 3-factor and 4-factor alphas from Panel A are 78 basis points $(t=1.08)$, 96 basis points $(t=1.39)$ and 58 basis points $(t=0.86)$ for this finer specification, or roughly $7-11 \%$ per year.
} 
determinants. ${ }^{19}$ If these connected board members are helpful in making strategically valuable decisions, and the market does not fully understand this (much like the strategic trading in Section B more generally), then we expect a positive coefficient on Pct of Board Strategically Connected. This is precisely what we see in all four columns of Table VIII. Examining both the full sample of firms, and solely the subsample of firms that have at least 1 connected board member (to test whether the percentage of board members, and not simply the existence of any connected board member relative to zero), we see a large and significant coefficient on Pct of Board Strategically Connected. To give an idea of magnitude, the coefficient in Column 4 of 0.077 $(t=2.13)$, implies that a firm with a strategically connected board member to the country it is trading with has future returns of 60 basis points per month higher than a firm trading with the same country but no connected board member.

\section{Analyst Attention to Information in Imports and Exports}

In Sections A-C above we showed that strategic importing and exporting had an impact on real firm outcomes, but that this impact was not fully understood by investors in setting market prices. In this section we test whether other, potentially more sophisticated financial agents, namely sell-side securities analysts, are better able to assess the large value of this strategic information link advantage. A large part of an analyst's job is to research, produce, and disclose reports forecasting aspects of companies' future prospects, and to translate their forecasts into earnings forecasts. Thus, we test whether analysts understand the value-enhancing nature of these strategic importing and exporting decisions by analyzing analysts' ability to correctly impound this information into their earnings forecasts of firms who exploit these strategic networks versus firms that do not.

We report two sets of tests of this idea in Table IX. The first test simply examines whether analysts are more inaccurate in their forecasts of strategic trading firms versus non-strategic trading firms. We do this using the variable Earnings

\footnotetext{
${ }^{19}$ Given the smaller number of firms that have board members from foreign countries in general, the portfolio approach of Table VII yielded too thin of portfolios, and so we utilize the Fama-MacBeth regression framework to test the thesis in Table VIII.
} 
Forecast Error, which is defined as is the absolute value of the actual reported earnings (EPS) minus the consensus mean of the most recent analyst forecasts of EPS (in the month leading up to the announcement), scaled by the absolute value of actual EPS reported..$^{20}$ We regress Earnings Forecast Error for each firm on whether or not the firm is a strategic importer (exporter), along with a number of other controls (from Table VIII), and fixed effects for month and industry. Standard errors are clustered at the monthly level. Columns 3 and 4 (and 7 and 8) tell a consistent story: analysts do not seem to be correctly taking into account the information in strategic importing or exporting, and so are significantly more inaccurate on these firms. To give an idea of the magnitude, the coefficient in Column 4 of $2.874(t=2.53)$ suggests that analysts are $15 \%$ less accurate on strategic exporting firms than on other firms. In contrast, we see no such inaccuracy on non-strategic importers or exporters, as analysts appear to be able to roughly correctly forecast their earnings, on average.

Given that firms' strategic trading yields real value in terms of future sales growth and profitability, and that both price setters and analysts seem to not fully understand or impound this information into prices, earnings announcements might be the exact times that the information embedded in these real quantities is impounded into prices (as it is revealed to the markets in these quarterly statements). We test this directly by examining whether the earnings surprise cumulative abnormal returns (CARs) of strategic traders are predictably different than those of non-strategic traders. Earnings Surprise CAR is defined as the cumulative abnormal return $(\mathrm{t}-1, \mathrm{t}+1)$ around the earnings date $(\mathrm{t})$. The main independent variable of interest (strategic importer (exporter)) remains the same, as do all controls and specifications, with the addition of one new control variable, (Act EPS - Est), controlling for the magnitude and direction of the actual earnings surprise itself. These regressions are in Columns 1 and 2 (and 5 and 6) of Table IX. All four columns show that strategic importers (exporters) have significantly larger Earnings Surprise CARs, consistent with these being times that the advantages of strategic trading are revealed to the market and impounded into prices. Again, we see no such increased Earnings Surprise CARs for the non-strategic firms.

\footnotetext{
${ }^{20}$ Following the literature (see DeGeorge et al. (1999)), we winsorize these at the 0.01 level to account for extreme values of the forecast errors.
} 
Taken together, the evidence in Section V indicates that it is precisely the firms that exploit their ethnic information links that achieve higher sales growth and profitability. Firms that exhibit the exact same behavior as these firms, but that do not have these ethnic links (i.e., non-strategic importers and exporters), experience neither of these favorable outcomes. Further, the market does not fully understand or incorporate this advantage into strategic firms' prices, generating predictably large, future abnormal returns (which also exist for firms exploiting connected boards). Lastly, analysts also do not appear to take into account the advantages of strategic importing and exporting, and so are significantly less accurate in their earnings forecasts on these strategic trading firms.

\section{Other Transactions and Connections}

In this section, we investigate whether firms that have connections to foreign countries through their connected resident populations (or through board members) report more business transactions in those countries. Specifically, we use geographical segment information filed by corporations to measure the amount of sales originated from a certain country or region, and test whether this is impacted by the firms' surrounding ethnic populations (and connected boards).

The dependent variable we use is the Segment Sales Ratio, which equals the sales of a foreign segment scaled by total sales reported in all foreign segments in that year. Data on sales in geographical segments are drawn from the Compustat geographic segment files. In these files, a geographic segment may refer to a specific country (e.g. China) or a region (Asia). Because the segments reported are not standardized, we created concordance files to map regions to companies using the United Nations Cartographic maps. We exclude observations that do not contain any geographic reference to a region or country. Our main independent variable of interest (as in Table III) is Connected Population. Connected Population refers to the number of residents in firm's headquarter MSA connected to a foreign country scaled by total population in that MSA $\left(\mathrm{CP}_{\mathrm{ct}}\right)$. We also include Connected Board Member, which takes the value of 1 if the firm has a board member who has an ethnicity tie to that country. We also include a number of control variables. The variable Number of Firms in Country equals 
the total number of firms reporting a segment sale in that country. By including this variable, we intend to capture the effect of the clustering of U.S. corporations doing business in certain countries. Number of Countries is the total number of unique countries a firm reported in its segment files. Segment Sales refers to sales of that segment in that particular year. We also include year and country fixed effects in each specification.

Table X shows that both Connected Population and Connected Board Member are statistically significant predictors of the Segment Sales Ratio. In terms of the magnitude, a one standard deviation increase in connected population (connected board member) increases segment sales by $1.8 \%(0.7 \%)$ in that country. This represents corroborating evidence to the results throughout the paper. Not only do surrounding ethnic populations impact the importing and exporting decisions of firms, but they have an impact on broader sales and expansion decisions of firms, as well.

\section{Conclusion}

In this paper, we exploit variation in ethnic population across the U.S. to examine how local residents' ties to their home-countries can influence firms' international trade decisions. We exploit novel customs and port authority data detailing the international shipments of all U.S. publicly-traded firms, and show that firms import and export significantly more with countries that have a strong resident population near their firm headquarters location. We use the formation of World War II Japanese Internment Camps to isolate exogenous shocks to local ethnic populations, and identify a causal link between local networks and firm trade.

We find that firms that exploit these local networks in their international trade decisions (strategic traders) experience significant increases in future sales growth and profitability. We show that although we can predict which trade links, on average, are valuable for firms using simple measures of connected population that are publicly available, the market seems to ignore this information. In particular, strategic importers and exporters outperform other importers and exporters by $5 \%-7 \%$ per year in risk-adjusted returns. The increased value of strategic traders is also missed by 
analysts, who are significantly less accurate in their earnings forecasts on these firms, with these firms having significantly more positive earnings surprises.

We then provide additional evidence on the mechanism by showing that at times when the information network represents a more valuable link, specifically at times of tariff cuts to the connected country, our effects are even larger. We show that one particular channel of the information network is through board members: a connected local population predicts more board members from that same country, and a significantly higher value for those firms that exploit connected board members in their trade decisions.

While we focus on immigration and how demographic factors affect the import and export behavior of firms, we believe that our approach can be readily adapted to study other local advantage factors. Our research also provides new evidence on the economic impact of immigration and ethnic diversity in the United States. Immigrants' conduit roles in economic transactions surely stretch far beyond those we document in this paper. 


\section{References}

Acemoglu, Daron, Vasco Carvalho, Asuman Ozdaglar and Alireza Tahbaz-Salehi, 2012, The network origins of aggregate fluctuations, Econometrica 80, 1977-2016.

Agarwal, Sanjeev and Sridhar Ramaswami, 1992, Choice of foreign market entry mode: Impact of ownership, location and internalization factors, Journal of International Business Studies 23, $1-27$.

Barber, Brad and Terrance Odean, 2008. All that glitters: The effect of attention and news on the buying behavior of individual and institutional investors. Review of Financial Studies 21, $785-818$.

Bernard, Andrew, J. Bradford Jensen, Stephen Redding and Peter Schott, 2007, Firms in international trade, Journal of Economic Perspectives 21, 105-130.

Burchardi, Konrad and Tarek Hassan, 2013, The economic impact of social ties:

Evidence from German reunification, Quarterly Journal of Economics (forthcoming).

Burton, Jeffrey, Mary Farrell, Florence Lord, and Richard Lord, 2000, Confinement and ethnicity: An overview of World War II Japanese American relocation sites, Western Archeological and Conservation Center, National Park Service, U.S. Department of the Interior.

Casella, Alessandra and James Rauch, 2002, Anonymous market and group ties in international trade, Journal of International Economics 58, 19-47.

Cavusgil, S. Tamer and John Nevin, 1981, Internal determinants of export marketing behavior: An empirical investigation, Journal of Marketing Research 18, 114-119.

Chaney, Thomas, 2012, The network structure of international trade, Working paper, University of Chicago.

Civil Liberties Public Education Fund (CLPEF), 1998, List of Detention Camps, Temporary Detention Centers, and Department of Justice Internment Camps.

Cohen, Lauren, Karl Diether and Christopher Malloy, 2013, Review of Financial Studies 26, 635-666.

Cohen, Lauren and Andrea Frazzini, 2008. Economic links and predictable returns. Journal of Finance 63, 1977-2011.

Cohen, Lauren and Dong Lou, 2012, Complicated firms, Journal of Financial Economics 104, 383-400.

Combes, Pierre-Philippe, Miren Lafourcade and Thierry Mayer, 2005, The trade creating effects of business and social networks: Evidence from France, Journal of International Economics 66, $1-29$.

Daniel, Roger, 1993, Prisoners without trial: Japanese Americans in World War II, Hill and Wang, New York, NY. 
DeGeorge, Francois, Jayendu Patel and Richard Zeckhauser, 1999, Earnings management to exceed thresholds, Journal of Business 72, 1-33.

DellaVigna, Stefano and Joshua Pollet, 2006. Investor inattention, firm reaction, and Friday earnings announcements, Journal of Finance 64, 709-749.

Duffie, Darrell, 2010, Asset price dynamics with slow-moving capital, Journal of Finance 65, $1237-1267$.

Field, Laura and Jonathan Karpoff, 2002, Takeover defenses of IPO firms, Journal of Finance $57,1857-1889$.

Garmendia, Aitor, Carlos Llano, Asier Minondo and Francisco Requena, 2012, Networks and the disappearance of the intranational home bias, Economics Letters 116, 178-182.

Gould, David, 1994, Immigrant links to the home country: Empirical implications for U.S. bilateral trade flows, Review of Economics and Statistics 76, 302-316.

Green, Robert and Arthur Allaway, 1985, Identification of export opportunities using the shiftshare approach, Journal of Marketing 49, 83-88.

Hidalgo, César, Bailey Klinger, Albert-László Barabási, and Ricardo Hausmann, 2007, The product space conditions the development of nations, Science 317, 482-487.

Hirshleifer, David, Sonya Lim and Siew Teoh, 2009, Driven to distraction: Extraneous events and underreaction to earnings news, Journal of Finance 64, 2289-2325.

Hong, Harrison and Jeremy Stein, 1999, A unified theory of underreaction, momentum trading, and overreaction in asset markets, Journal of Finance 54, 2143-2184.

Hong, Harrison and Jeremy Stein, 2007, Disagreement and the stock market, Journal of Economic Perspectives 21, 109-128.

Hong, Harrison, Walter Tourus, Rossen Valkanov, 2007, Do industries lead the stock market?, Journal of Financial Economics 83, 367-396.

Hou, Kewei, 2007, Industry information diffusion and the lead-lag effect in stock returns, Review of Financial Studies 20, 1113-1138.

Huang, Xing, 2012, Gradual information diffusion in the stock market: Evidence from U.S. multinational firms. UC Berkeley working paper.

Huberman, Gur and Tomer Regev, 2001. Contagious speculation and a cure for cancer: a nonevent that made stock prices soar, Journal of Finance 56, 387-396.

Ina, Satsuki, Kim Ina, Audrey Kasho-Wells, Stephen Holsapple and Emery Clay, 1999, The children of the camps project, Public Broadcasting Service.

Loree, David and Stephen Guisinger, 1995, Policy and non-policy determinants of U.S. equity foreign direct investment, Journal of International Business Studies 26, 281-299. 
Loughran, Tim and Jay Ritter, 2004, Why has IPO underpricing changed over time?, Financial Management 33, 5-37.

Merton, Robert, 1987. A simple model of capital market equilibrium with incomplete information, Journal of Finance 42, 483-510.

Mitra, Debanjan and Peter Golder, 2002, Whose culture matters? Near-Market knowledge and its impact on foreign market entry timing, Journal of Marketing Research 39, 350-365.

Nguyen, Quoc, 2012. Geographic momentum. University of Illinois working paper.

Okamoto, Tomochika, 2000, Changes in the representation of "Japanese Americans" in U. S. History Textbooks, 1952-1999, 52 ${ }^{\text {nd }}$ Annual Meeting of the Japan Society of Educational Sociology.

Pan, Yigang, Shaomin Li and David Tse, 1999, The impact of order and mode of market entry on profitability and market share, Journal of International Business Studies 30, 81-104.

Rauch, James, 1999, Networks versus markets in international trade, Journal of Economic Literature 48, 7-35.

Rauch, James, 2001, Business and social networks in international trade, Journal of Economic Literature 39, 1177-1203.

Rauch, James and Vitor Trindade, 2002, Ethnic Chinese networks in international trade, Journal of International Economics 84, 116-130. 


\section{Figure 1: Japanese Internment Camps of World War II}

This figure presents summary statistics on aspects related to the Japanese Internment Camps of World War II. Panel A shows a map of the US, indication where the ten internment camps were located, delineating them with a old text with a dot (Daniel (1993)). Panel B gives the location of the 10 internment camps, along with peak populations in each camp (CLPEF (1998)). Panel C shows the Japanese population in 1940 in each of the seven states that would later house internment camps, from the United States Census of 1940.

\section{Panel A: Map of 10 Internment Camps}

\section{THE WRA RELOCATION CAMPS, 1942.1946}

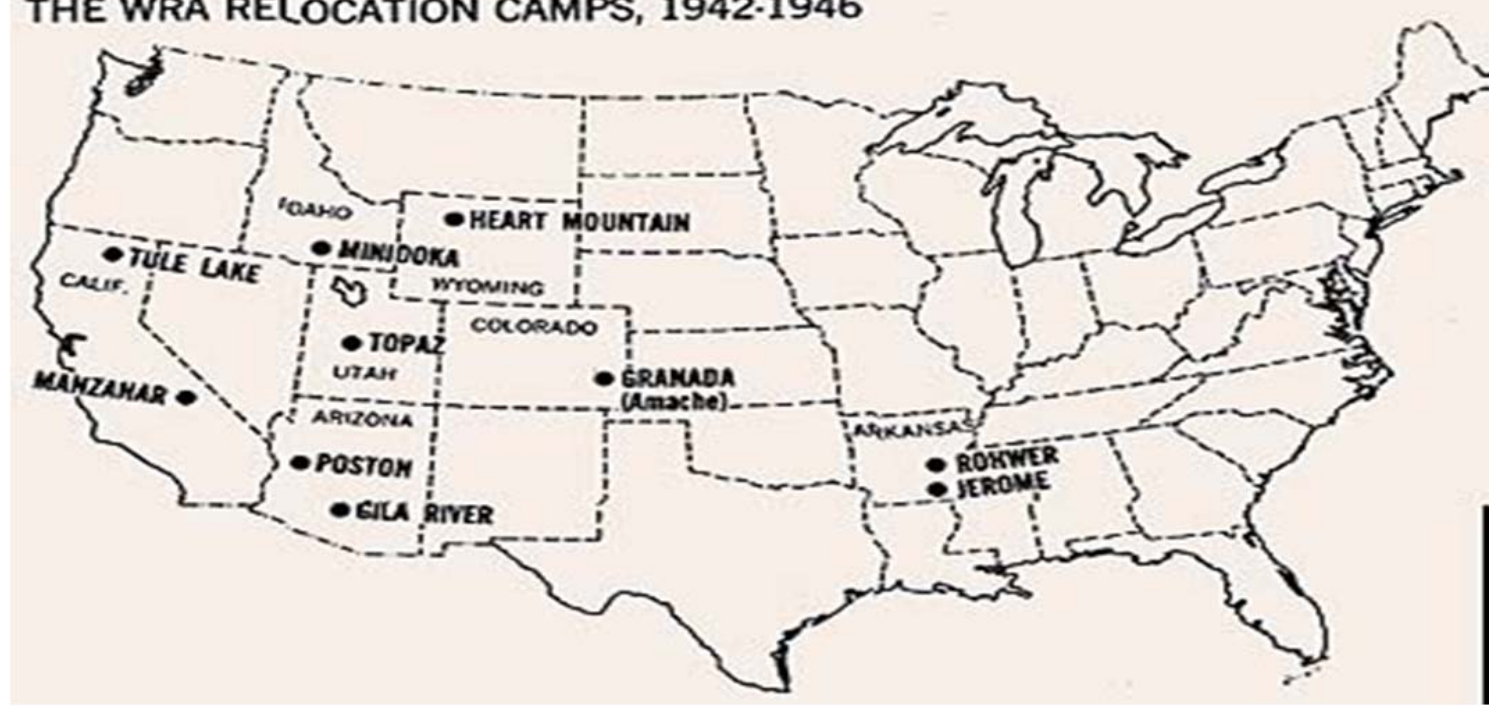

Panel B: Populations of 10 Internment Camps

\begin{tabular}{llllll}
\hline & & Date of first & Peak & & $\begin{array}{l}\text { Date of last } \\
\text { prisoner } \\
\text { Center }\end{array}$ \\
Strival & State & Population & Date of peak & left(?) \\
\hline Gila River & AZ & $7 / 20 / 42$ & 13,348 & $12 / 30 / 42$ & $11 / 10 / 45$ \\
Heanada & CO & $8 / 27 / 42$ & 7,318 & $2 / 1 / 43$ & $10 / 15 / 45$ \\
Jerome & WY & $8 / 12 / 42$ & 10,767 & $1 / 1 / 43$ & $11 / 10 / 45$ \\
Manzanar & AR & $10 / 6 / 42$ & 8,497 & $2 / 11 / 43$ & $6 / 30 / 44$ \\
Minidoka & CA & $3 / 21 / 42$ & 10,046 & $9 / 22 / 42$ & $11 / 21 / 45$ \\
Poston & ID & $8 / 10 / 42$ & 9,397 & $3 / 1 / 43$ & $10 / 28 / 45$ \\
Rohwer & AZ & $5 / 8 / 42$ & 17,814 & $9 / 2 / 42$ & $11 / 28 / 45$ \\
Topaz & AR & $9 / 18 / 42$ & 8,475 & $3 / 11 / 43$ & $11 / 30 / 45$ \\
Tule Lake & UT & $9 / 11 / 42$ & 8,130 & $3 / 17 / 43$ & $10 / 31 / 45$ \\
\hline
\end{tabular}

Panel C: Pre-Internment Camps Population (from 1940 census)

\begin{tabular}{llll}
\hline State & ST & Total Population & Japanese Population \\
\hline Arizona & AZ & 499,261 & 632 \\
Arkansas & AR & $1,949,387$ & 3 \\
California & CA & $6,907,367$ & 93,717 \\
Colorado & CO & 123,296 & 2,734 \\
Idaho & ID & 524,873 & 1,191 \\
Utah & UT & 550,310 & 2,210 \\
Wyoming & WY & 250,742 & 643 \\
\hline
\end{tabular}




\section{Table I: Summary Statistics for Importers and Exporters}

This table presents summary statistics on the firms included in the tests. MVE is the market value of equity calculated as the price end of calendar year prior to fiscal year end multiplied by number of shares outstanding. $\mathrm{B} / \mathrm{M}$ is the book to market ratio where the book value of equity is calculated as sum of stock holders equity (SEQ), Deferred Tax (TXDB), Investment Tax Credit (ITCB) minus Preferred Stock (PREF). Leverage is long-term debt (DLTT) plus debt in current liabilities (DLC), divided by the numerator plus market equity. Past Return is the twelve month return prior to fiscal year end. ROA (return on asset) earnings before tax and depreciation (EBITDA) scaled by total assets (TA). PPE/TA is the ratio of plant, property, and equity (PPENT) scaled by total assets. The unit of observation is firm-year. Panel A (B) reports the summary statistics for public firms, which exported (imported) at least once in a given year. The sample period covers 1994 to 2010. Panel C reports the industry breakdown of importers and exporters by 2-digit NAICS code.

Panel A: Firm level data for exporters

\begin{tabular}{lllllll}
\hline & MVE & B/M & Leverage & Past Return & ROA & PPE/TA \\
\hline mean & 4,929 & 0.723 & 0.223 & 0.175 & 0.119 & 0.284 \\
sd & 20,899 & 1.591 & 0.174 & 0.714 & 0.146 & 0.201 \\
p5 & 9 & 0.125 & 0.000 & -0.558 & -0.066 & 0.029 \\
p10 & 19 & 0.185 & 0.000 & -0.419 & 0.015 & 0.059 \\
p25 & 74 & 0.314 & 0.071 & -0.177 & 0.078 & 0.132 \\
p50 & 404 & 0.527 & 0.209 & 0.081 & 0.129 & 0.241 \\
p75 & 2,044 & 0.858 & 0.339 & 0.365 & 0.182 & 0.392 \\
p90 & 8,598 & 1.345 & 0.455 & 0.754 & 0.239 & 0.579 \\
p95 & 20,142 & 1.822 & 0.534 & 1.158 & 0.279 & 0.692 \\
N & 20,073 & 20,073 & 20,122 & 19,713 & 20,021 & 20,046 \\
\hline
\end{tabular}

Panel B: Firm level data for Importers

\begin{tabular}{lllllll}
\hline & MVE & B/M & Leverage & Past Return & ROA & PPE/TA \\
\hline mean & 4,889 & 0.711 & 0.211 & 0.182 & 0.107 & 0.265 \\
sd & 20,595 & 0.934 & 0.175 & 0.783 & 0.160 & 0.201 \\
p5 & 11 & 0.127 & 0.000 & -0.583 & -0.104 & 0.020 \\
p10 & 23 & 0.185 & 0.000 & -0.434 & -0.003 & 0.043 \\
p25 & 87 & 0.313 & 0.051 & -0.187 & 0.068 & 0.109 \\
p50 & 455 & 0.523 & 0.195 & 0.078 & 0.122 & 0.220 \\
p75 & 2,110 & 0.847 & 0.328 & 0.371 & 0.175 & 0.372 \\
p90 & 8,626 & 1.320 & 0.448 & 0.789 & 0.232 & 0.564 \\
p95 & 19,450 & 1.800 & 0.528 & 1.208 & 0.273 & 0.676 \\
N & 23,743 & 23,743 & 23,787 & 23,298 & 23,687 & 23,722 \\
\hline
\end{tabular}




\section{Table I: Summary Statistics (continued)}

Panel C: Industry Breakdown of Exporters and Importers

\begin{tabular}{llll}
\multicolumn{3}{l}{ NAICS 2 Importers Exporters } & Pefinition \\
\hline 11 & 17 & 16 & Agriculture, Forestry, Fishing and Hunting \\
21 & 114 & 112 & Mining, Quarrying, and Oil and Gas Extraction \\
22 & 78 & 52 & Utilities \\
23 & 43 & 39 & Construction \\
$31-33$ & 2,358 & 1,994 & Manufacturing \\
42 & 194 & 184 & Wholesale Trade \\
$44-45$ & 340 & 274 & Retail Trade \\
$48-49$ & 93 & 80 & Transportation and Warehousing \\
51 & 290 & 163 & Information \\
52 & 245 & 169 & Finance and Insurance \\
$53-54$ & 221 & 159 & Professional, Scientific, and Technical Services \\
56 & 77 & 58 & Admin/Support/Waste Management and Remediation Services \\
61 & 8 & 4 & Educational Services \\
62 & 36 & 32 & Health Care and Social Assistance \\
71 & 19 & 13 & Arts, Entertainment, and Recreation \\
72 & 59 & 43 & Accommodation and Food Services \\
81 & 49 & 39 & Other Services (except Public Administration) \\
\hline Total & 4,241 & 3,431 &
\end{tabular}




\section{Table II: Major U.S. and Foreign Ports}

This table reports the top 5 ports used by the sample firms for imports and exports in U.S. and foreign countries. The figures reported are annual dollar value of imports and exports (in billions) throughout the sample period (1994-2010).

Panel A: Top 5 Importing U.S. Ports

\begin{tabular}{ll}
\hline LOS ANGELES & 185 \\
LONG BEACH & 159 \\
NEW YORK & 95 \\
SEATTLE & 62 \\
NORFOLK & 61 \\
\hline
\end{tabular}

Panel B: Top 5 Exporting U.S. Ports

\begin{tabular}{ll}
\hline HOUSTON & 110 \\
LOS ANGELES & 85 \\
NEW YORK & 75 \\
NORFOLK & 66 \\
CHARLESTON & 61 \\
\hline
\end{tabular}

Panel C: Top 5 Origination Ports for U.S. Imports

\begin{tabular}{ll}
\hline HONG KONG & 125 \\
RICHARDS BAY & 105 \\
YANTIAN & 76 \\
KAOHSIUNG & 63 \\
SHANGHAI & 61 \\
\hline
\end{tabular}

Panel D: Top 5 Destination Ports for U.S. Exports

\begin{tabular}{ll}
\hline ANTWERP & 66 \\
ROTTERDAM & 57 \\
VANCOUVER & 50 \\
HONG KONG & 43 \\
SINGAPORE & 37 \\
\hline
\end{tabular}




\section{Table III: The Impact of Ethnic Connections on Firm-Level Trade}

Panel A (first four columns) of this table presents coefficient estimates of fixed effects regressions of export ratio (ER) on Connected Population $(\mathrm{CP})$ and control variables: $\mathrm{ER}_{\text {ict }}=\mathrm{b} 1+\mathrm{b} 2 * \mathrm{CP}_{\mathrm{ct}}$ + b3* Connected Board Member + fixed effects. Export Ratio (ER) is total amount a given firm exports to a destination country in a given year scaled by total amount of exports of the same firm in the same year $\left(\mathrm{E}_{\mathrm{ict}} / \mathrm{Sum}\left(\mathrm{E}_{\mathrm{it}}\right)\right)$. Connected population is the number of residents in a firm's headquarter MSA connected to the export country scaled by total population in that state $\left(\mathrm{CP}_{\mathrm{ct}}\right)$. Connected Board Member is a binary variable that takes a value of 1 if the firm has a board member with an ethnic background the same as the export destination. The dependent variable in the last column is a dummy variable, which takes a value of one if the firm has exported to a given country in a given year. Panel B (first four columns) of this table presents coefficient estimates of the following specification: $\mathrm{IR}_{\text {ict }}=\mathrm{b} 1+\mathrm{b} 2 * \mathrm{CP}_{\mathrm{ct}}+\mathrm{b} 3 *$ Connected Board Member + fixed effects, where import ratio (IR) is total amount a given firm imports from a country in a given year scaled by total amount of imports of the same firm in the same year $\left(\mathrm{I}_{\text {ict }}\right.$ $\left./ \operatorname{Sum}\left(\mathrm{I}_{\mathrm{it}}\right)\right)$. The dependent variable in the last column is a dummy variable, which takes a value of one if the firm has imported from a given country in a given year. T-stats, clustered by year, are reported below coefficient estimates. ${ }^{*}, * *$, and $* * *$ indicate statistical significance at the $10 \%$, $5 \%$, and $1 \%$ levels, respectively.

Panel A: Exports

\begin{tabular}{|c|c|c|c|c|c|}
\hline & $\begin{array}{l}\text { Export } \\
\text { Ratio }\end{array}$ & $\begin{array}{l}\text { Export } \\
\text { Ratio }\end{array}$ & $\begin{array}{l}\text { Export } \\
\text { Ratio }\end{array}$ & $\begin{array}{l}\text { Export } \\
\text { Ratio }\end{array}$ & $\begin{array}{l}\text { Export } \\
\text { Ratio } \\
\text { (extensive } \\
\text { margin) }\end{array}$ \\
\hline Connected Population & $\begin{array}{l}0.039^{* * *} \\
(5.14)\end{array}$ & $\begin{array}{l}0.039 * * * \\
(4.71)\end{array}$ & $\begin{array}{l}0.122^{\text {*** }} \\
(4.35)\end{array}$ & $\begin{array}{l}0.043^{* * *} \\
(5.42)\end{array}$ & $\begin{array}{l}0.0457^{* * *} \\
(30.34)\end{array}$ \\
\hline Connected Board Member & & & & $\begin{array}{l}0.014^{* * *} \\
(3.42)\end{array}$ & \\
\hline Firm Fixed Effects & Yes & No & No & No & No \\
\hline Year Fixed Effects & Yes & No & No & No & No \\
\hline Firm x Year Fixed Effects & No & Yes & No & Yes & No \\
\hline Country Fixed Effects & Yes & Yes & No & Yes & No \\
\hline State x Partner Country Fixed Effects & No & No & Yes & No & Yes \\
\hline Adj. R2 & 0.46 & 0.59 & 0.10 & 0.59 & 0.002 \\
\hline Number of Observations & 80,529 & 80,529 & 80,529 & 80,529 & $2,966,539$ \\
\hline
\end{tabular}


Table III: The Impact of Ethnic Connections on Firm-Level Trade (continued)

Panel B: Imports

\begin{tabular}{|c|c|c|c|c|c|}
\hline & $\begin{array}{l}\text { Import } \\
\text { Ratio }\end{array}$ & $\begin{array}{l}\text { Import } \\
\text { Ratio }\end{array}$ & $\begin{array}{l}\text { Import } \\
\text { Ratio }\end{array}$ & $\begin{array}{l}\text { Import } \\
\text { Ratio }\end{array}$ & $\begin{array}{l}\text { Import } \\
\text { Ratio } \\
\text { (extensive } \\
\text { margin) }\end{array}$ \\
\hline Connected Population & $\begin{array}{l}0.022^{* *} \\
(2.00)\end{array}$ & $\begin{array}{l}0.032^{* * *} \\
(2.70)\end{array}$ & $\begin{array}{l}0.154^{* * *} \\
(5.97)\end{array}$ & $\begin{array}{l}0.035^{* * *} \\
(3.04)\end{array}$ & $\begin{array}{l}0.0578^{* * *} \\
(25.56)\end{array}$ \\
\hline Connected Board Member & & & & $\begin{array}{l}0.015^{* * *} \\
(4.94)\end{array}$ & \\
\hline Firm Fixed Effects & Yes & No & No & No & No \\
\hline Year Fixed Effects & Yes & No & No & No & No \\
\hline Firm x Year Fixed Effects & No & Yes & No & Yes & No \\
\hline Country Fixed Effects & Yes & Yes & No & Yes & No \\
\hline State x Partner Country Fixed Effects & No & No & Yes & No & Yes \\
\hline Adj. R2 & 0.39 & 0.49 & 0.10 & 0.49 & 0.003 \\
\hline Number of Observations & 84,296 & 84,296 & 84,296 & 84,296 & $2,634,115$ \\
\hline
\end{tabular}




\section{Table IV: Tariff and Differentiated Product Analysis}

The first four columns in this table presents coefficient estimates of fixed effects regressions of product import ratio (PIR) on Connected Population $(\mathrm{CP})$ and control variables: $\mathrm{PIR}_{\mathrm{icpt}}=\mathrm{b} 1+\mathrm{b} 2 * \mathrm{CP}_{\mathrm{ct}}+\mathrm{b} 3 *$ Tariff $+\mathrm{b} 4 * \mathrm{CP}_{\mathrm{ct}} \mathrm{x}$ Tariff + Fixed Effects. Product Import Ratio $(\mathrm{PIR})$ is total amount a given firm imports from a foreign country in a given year scaled by total amount of imports of the same firm in the same year $\left(\mathrm{I}_{\text {icp }}\right.$ $\left./ \operatorname{Sum}\left(\mathrm{I}_{\mathrm{it}}\right)\right)$. Connected population is the number of residents in a firm's headquarter MSA connected to the import country scaled by total population in that state $\left(\mathrm{CP}_{\mathrm{ct}}\right)$. Tariff is the value of the US tariff on the given product to the given country, taken from the TRAINS dataset maintained by United Nations Conference on Trade and Development (UNCTAD). In the last two columns, we introduce a variable that denotes whether the product is a differentiated product as defined by Rauch (1999). Fixed effects for firm, year, and product are included where indicated. T-stats, clustered by year, are reported below coefficient estimates. *, **, and *** indicate statistical significance at the $10 \%, 5 \%$, and $1 \%$ levels, respectively.

\begin{tabular}{|c|c|c|c|c|c|c|}
\hline & $\begin{array}{c}\text { Product Import } \\
\text { Ratio }\end{array}$ & $\begin{array}{c}\text { Product Import } \\
\text { Ratio }\end{array}$ & $\begin{array}{c}\text { Product Import } \\
\text { Ratio }\end{array}$ & $\begin{array}{c}\text { Product Import } \\
\text { Ratio }\end{array}$ & $\begin{array}{c}\text { Product Import } \\
\text { Ratio }\end{array}$ & $\begin{array}{c}\text { Product Export } \\
\text { Ratio }\end{array}$ \\
\hline Connected Population & $\begin{array}{c}0.0046^{* *} \\
(2.43)\end{array}$ & $\begin{array}{c}0.0046^{* *} \\
(2.46)\end{array}$ & $\begin{array}{c}0.0074^{* * *} \\
(3.93)\end{array}$ & $\begin{array}{l}0.0020 \\
(1.06)\end{array}$ & $\begin{array}{c}0.0029 * * * \\
(2.29)\end{array}$ & $\begin{array}{c}0.0018^{* * *} \\
(8.39)\end{array}$ \\
\hline Tariff & & $\begin{array}{c}-0.00003 \\
(0.18)\end{array}$ & $\begin{array}{c}0.0001 \\
(0.73)\end{array}$ & $\begin{array}{c}0.0004 \\
(1.61)\end{array}$ & & \\
\hline Connected Population x Tariff & & & $\begin{array}{c}-0.0022^{* * *} \\
(4.49)\end{array}$ & $\begin{array}{c}-0.0014^{* * *} \\
(3.48)\end{array}$ & & \\
\hline Differentiated Product & & & & & $\begin{array}{l}0.0074^{* * *} \\
\quad(2.41)\end{array}$ & $\begin{array}{l}0.0049^{* * *} \\
\quad(9.10)\end{array}$ \\
\hline Connected Population x Differentiated Product & & & & & $\begin{array}{c}0.0042^{* * *} \\
\quad(4.61)\end{array}$ & $\begin{array}{c}-0.0011 \\
(1.37)\end{array}$ \\
\hline Firm Fixed Effects & Yes & Yes & Yes & Yes & Yes & Yes \\
\hline Year Fixed Effects & Yes & Yes & Yes & Yes & Yes & Yes \\
\hline Product Fixed Effects & No & No & No & Yes & No & No \\
\hline Adj. R2 & 0.40 & 0.40 & 0.40 & 0.48 & 0.41 & 0.47 \\
\hline Number of Observations & 34,062 & 34,062 & 34,062 & 34,062 & 563,552 & 422,237 \\
\hline
\end{tabular}




\section{Table V: Instrumental Variable Analysis: Japanese Internment Camps}

This table presents the instrumental variable estimation for exports (imports) in Columns 1 and 2 (3 and 4) of Panels A and B. The sample includes only the exports to (or imports from) Japan. Export Ratio (ER) is total amount a given firm exports to a destination country in a given year scaled by total amount of exports of the same firm in the same year $\left(E_{\text {ict }} / \operatorname{Sum}\left(E_{\text {it }}\right)\right)$. Import ratio (IR) is total amount a given firm imports from a country in a given year scaled by total amount of imports of the same firm in the same year $\left(\mathrm{I}_{\mathrm{ict}} / \operatorname{Sum}\left(\mathrm{I}_{\mathrm{it}}\right)\right)$. Connected population is the number of residents in a firm's headquarter MSA connected to the export (import) country scaled by total population in that state $\left(\mathrm{CP}_{\mathrm{ct}}\right)$. The instrument, Japanese Internment is a categorical variable that takes a value of 1 if the headquarter of the firm is located in a state that housed one of the internment camps. Immigration from Asia refers to the growth rate of Asian-Pacific Islander ethnicities except Japanese (e.g. Korean, Chinese, Hindu and Filipino), measured as the ratio in 1990 to that of 1930. All standard errors are adjusted for clustering at the state level, and t-stats using these clustered standard errors are included in parentheses below the coefficient estimates. $*, * *$, and ${ }^{* *}$ indicate statistical significance at the $10 \%, 5 \%$, and $1 \%$ levels, respectively.

\begin{tabular}{|c|c|c|c|c|}
\hline $\begin{array}{l}\text { Panel A: First Stage } \\
\text { Sample Trade Firms: }\end{array}$ & Exporters & Exporters & Importers & Importers \\
\hline Dependent Variable: & $\begin{array}{l}\text { Connected } \\
\text { Population } \\
\end{array}$ & $\begin{array}{l}\text { Connected } \\
\text { Population } \\
\end{array}$ & $\begin{array}{l}\text { Connected } \\
\text { Population } \\
\end{array}$ & $\begin{array}{l}\text { Connected } \\
\text { Population } \\
\end{array}$ \\
\hline Japanese Internment & $\begin{array}{l}0.0083^{* * *} \\
\quad(3.61)\end{array}$ & $\begin{array}{c}0.0079^{* * *} \\
(3.41)\end{array}$ & $\begin{array}{c}0.0101^{* * *} \\
(4.91)\end{array}$ & $\begin{array}{c}0.0098^{* * *} \\
(4.65)\end{array}$ \\
\hline Immigration from Asia & & $\begin{array}{c}-0.0006^{*} \\
(1.70)\end{array}$ & & $\begin{array}{c}-0.0005^{*} \\
(1.78)\end{array}$ \\
\hline $\begin{array}{l}\text { Year Fixed Effects } \\
\mathrm{R}^{2} \\
\text { Number of Observations }\end{array}$ & $\begin{array}{r}\text { Yes } \\
0.47 \\
3165 \\
\end{array}$ & $\begin{array}{r}\text { Yes } \\
0.49 \\
3165 \\
\end{array}$ & $\begin{array}{r}\text { Yes } \\
0.61 \\
4804 \\
\end{array}$ & $\begin{array}{l}\text { Yes } \\
0.62 \\
4804 \\
\end{array}$ \\
\hline $\begin{array}{l}\text { Panel B: Second Stage } \\
\text { Sample Trade Firms: }\end{array}$ & Exporters & Exporters & Importers & Importers \\
\hline Dependent Variable: & $\begin{array}{l}\text { Export } \\
\text { Ratio } \\
\end{array}$ & $\begin{array}{l}\text { Export } \\
\text { Ratio } \\
\end{array}$ & $\begin{array}{c}\text { Import } \\
\text { Ratio } \\
\end{array}$ & $\begin{array}{l}\text { Import } \\
\text { Ratio }\end{array}$ \\
\hline $\begin{array}{l}\text { Instrumented } \\
\text { Connected Population }\end{array}$ & $\begin{array}{c}11.593^{* * *} \\
(3.02)\end{array}$ & $\begin{array}{c}11.670^{* * *} \\
(2.84)\end{array}$ & $\begin{array}{c}8.617^{* * *} \\
(4.11)\end{array}$ & $\begin{array}{c}7.992^{* * *} \\
(3.62)\end{array}$ \\
\hline Immigration from Asia & & $\begin{array}{l}0.0001 \\
(0.13)\end{array}$ & & $\begin{array}{c}-0.0091 \\
(1.15)\end{array}$ \\
\hline $\begin{array}{l}\text { Year Fixed Effects } \\
\mathrm{R}^{2} \\
\text { Number of Observations }\end{array}$ & $\begin{array}{l}\text { Yes } \\
0.03 \\
3165\end{array}$ & $\begin{array}{l}\text { Yes } \\
0.03 \\
3165\end{array}$ & $\begin{array}{l}\text { Yes } \\
0.04 \\
4804\end{array}$ & $\begin{array}{l}\text { Yes } \\
0.04 \\
4804\end{array}$ \\
\hline
\end{tabular}


Table V: Instrumental Variable Analysis: (continued)

\begin{tabular}{|c|c|c|c|c|}
\hline \multicolumn{5}{|c|}{ Panel C: Corroborative Evidence and Placebo Test } \\
\hline Dependent Variable: & $\begin{array}{c}\text { \# of } \\
\text { Japanese } \\
\text { Sister } \\
\text { Cities }\end{array}$ & $\begin{array}{c}\text { Connected } \\
\text { Population } \\
\text { to Japan }\end{array}$ & $\begin{array}{c}\text { Connected } \\
\text { Population } \\
\text { to Other } \\
\text { Asian } \\
\text { Ethnicities } \\
\end{array}$ & $\begin{array}{c}\text { Connected } \\
\text { Population } \\
\text { to Japan }\end{array}$ \\
\hline Japanese Internment & $\begin{array}{c}6.22^{* *} \\
(2.10)\end{array}$ & $\begin{array}{c}0.0028^{* * *} \\
(3.42)\end{array}$ & $\begin{array}{c}0.0015 \\
(1.25)\end{array}$ & $\begin{array}{c}0.0021^{* * *} \\
(3.50)\end{array}$ \\
\hline Other Asian Ethnicities & & & & $\begin{array}{c}0.4965^{* * *} \\
(6.49)\end{array}$ \\
\hline Constant & $\begin{array}{c}2.95^{* *} \\
(2.70)\end{array}$ & $\begin{array}{c}0.0016^{* * *} \\
\quad(5.23)\end{array}$ & $\begin{array}{c}0.0024^{* * *} \\
(5.56)\end{array}$ & $\begin{array}{c}0.0004 \\
(1.36)\end{array}$ \\
\hline $\mathrm{R}^{2}$ & 0.10 & 0.22 & 0.04 & 0.61 \\
\hline Sample Size (\# of States) & 44 & 44 & 44 & 44 \\
\hline
\end{tabular}




\section{Table VI: Real Effects of Strategic Trading Activity}

This table reports panel regressions of different measures of future firm-level real outcomes on lagged strategic trading activity. For exports, we first create buy/sell signals based on a firm's export amount in a given month, its destination country, and the match between the destination country's ethnicity and the firm's headquarter MSA's (metropolitan statistical area) ethnic composition. We use the American Communities Project (ACP) ethnicity classifications, and match these to destination countries as shown in Appendix Table A2. In every year for each MSA, we compute the share of each ethnicity that resides in each MSA. We then rank the share of each ethnicity across all MSAs in the US. The buy signal equals one if (i) a firm's share of total industry exports to a given country in a given month is ranked in the top 3, and (ii) the firm is located in an MSA where the MSA's ethnicity share across all MSAs in the US is ranked in the top 3. The sell signal equals one if (i) a firm's share of total industry exports to a given country is ranked in the top 3, but (ii) the firm is *not* located in an MSA where the MSA's ethnicity share across all MSAs in the US is ranked in the top 3. We define a firm as strategic exporter if the firm has at least one buy signal for any of its exports in a given year. A firm is defined as a non-strategic exporter if it has zero buy signals in a given year, and has at least one sell signal. The dependent variables are: 1) future sales (in year $t+1$ ) divided by lagged assets (in year $t$ ); and 2) ROA (defined as future EBITDA in year $t+1$ divided by lagged assets in year $t$ ). Control variables include Size (log of market capitalization), B/M (log of the book-to-market ratio), Leverage (long-term debt in year $t$ divided by lagged assets in year $t$ ), and Cash (future Cash in year $t+1$ divided by lagged assets in year $t$ ). Fixed effects for time (year) and firm are included in all regressions. $t$-stats, clustered by year, are reported below coefficient estimates. $*, * *$, and ${ }^{* * *}$ indicate statistical significance at the $10 \%, 5 \%$, and $1 \%$ levels, respectively.

\begin{tabular}{|c|c|c|c|c|c|c|c|c|}
\hline & \multicolumn{2}{|c|}{ Sales $_{t+1} /$ Assets $_{t}$} & \multicolumn{2}{|c|}{ EBITDA $_{t+1} /$ Assets $_{t}$} & \multicolumn{2}{|c|}{ Sales $_{t+1} /$ Assets $_{t}$} & \multicolumn{2}{|c|}{ EBITDA $_{t+1} /$ Assets $_{t}$} \\
\hline & (1) & $(2)$ & (3) & (4) & (5) & (6) & (7) & (8) \\
\hline Strategic Exporter & $\begin{array}{l}0.026^{* * *} \\
(2.89)\end{array}$ & $\begin{array}{l}0.021^{* *} \\
(2.16)\end{array}$ & $\begin{array}{l}0.009^{*} \\
(2.05)\end{array}$ & $\begin{array}{l}0.010^{* *} \\
(2.47)\end{array}$ & & & & \\
\hline Non-Strategic Exporter & $\begin{array}{l}-0.000 \\
(0.01)\end{array}$ & $\begin{array}{l}0.001 \\
(0.15)\end{array}$ & $\begin{array}{l}-0.006^{* * *} \\
(2.95)\end{array}$ & $\begin{array}{l}-0.006^{* * *} \\
(3.14)\end{array}$ & & & & \\
\hline Strategic Importer & & & & & $\begin{array}{l}0.019^{* * *} \\
(3.24)\end{array}$ & $\begin{array}{l}0.021^{* * *} \\
(3.86)\end{array}$ & $\begin{array}{l}0.005 \\
(0.64)\end{array}$ & $\begin{array}{l}0.001 \\
(0.015)\end{array}$ \\
\hline Non-Strategic Importer & & & & & $\begin{array}{l}0.002 \\
(0.72)\end{array}$ & $\begin{array}{l}0.004 \\
(1.14)\end{array}$ & $\begin{array}{l}0.001 \\
(0.36)\end{array}$ & $\begin{array}{l}0.001 \\
(0.24)\end{array}$ \\
\hline Size & & $\begin{array}{l}-0.048^{* * *} \\
(13.47)\end{array}$ & & $\begin{array}{l}0.011^{* *} \\
(2.32)\end{array}$ & & $\begin{array}{l}-0.054^{* * *} \\
(14.48)\end{array}$ & & $\begin{array}{l}0.011^{* *} \\
(3.13)\end{array}$ \\
\hline $\mathrm{B} / \mathrm{M}$ & & $\begin{array}{l}-0.122^{* * *} \\
(7.99)\end{array}$ & & $\begin{array}{l}-0.063^{* * *} \\
(4.82)\end{array}$ & & $\begin{array}{l}-0.134^{* * *} \\
(8.53)\end{array}$ & & $\begin{array}{l}-0.070^{* * *} \\
(6.03)\end{array}$ \\
\hline Leverage & & $\begin{array}{l}-0.478 \\
(1.72)\end{array}$ & & $\begin{array}{l}-0.014 \\
(0.05)\end{array}$ & & $\begin{array}{l}-0.003 \\
(0.01)\end{array}$ & & $\begin{array}{l}-0.419 \\
(1.02)\end{array}$ \\
\hline $\mathrm{Cash}_{\mathrm{t}+1} / \mathrm{A}_{\mathrm{t}}$ & & $\begin{array}{l}-1.448^{* *} \\
(2.52)\end{array}$ & & $\begin{array}{l}-0.270 \\
(0.40)\end{array}$ & & $\begin{array}{l}-1.686^{* * *} \\
(3.33)\end{array}$ & & $\begin{array}{l}-1.508 \\
(1.43)\end{array}$ \\
\hline Time Fixed Effects & Yes & Yes & Yes & Yes & Yes & Yes & Yes & Yes \\
\hline Firm Fixed Effects & Yes & Yes & Yes & Yes & Yes & Yes & Yes & Yes \\
\hline Adjusted $R^{2}$ & 0.88 & 0.89 & 0.68 & 0.69 & 0.89 & 0.90 & 0.66 & 0.68 \\
\hline No. of Obs. & 14,260 & 14,203 & 14,205 & 14,152 & 17,412 & 17,345 & 17,343 & 17,279 \\
\hline
\end{tabular}




\section{Table VII: Portfolio Returns to Strategic Trading Activity}

This table presents value-weight returns to calendar-time portfolios that buys stocks of strategic exporters and sell stocks of non-strategic exporters. In Panel A, we first create buy/sell signals based on a firm's export amount in a given month, its destination country, and the match between the destination country's ethnicity and the firm's headquarter MSA's (metropolitan statistical area) ethnic composition. We use the American Communities Project (ACP) ethnicity classifications, and match these to destination countries as shown in Appendix Table A2. In every year for each MSA, we compute the share of each ethnicity that resides in each MSA. In every year for each MSA, we compute the share of each ethnicity that resides in each MSA. We then rank the share of each ethnicity across all MSAs in the US. The buy signal equals one if (i) a firm's share of total industry exports to a given country in a given month is ranked in the top 3, and (ii) the firm is located in an MSA where the MSA's ethnicity share across all MSAs in the US is ranked in the top 3. The sell signal equals one if (i) a firm's share of total industry exports to a given country is ranked in the top 3, but (ii) the firm is *not* located in an MSA where the MSA's ethnicity share across all MSAs in the US is ranked in the top 3. We define a firm as strategic exporter if the firm has at least one buy signal for any of its exports in a given month. A firm is defined as a non-strategic exporter if it has zero buy signals in a given month, and has at least one sell signal. Each month we construct calendar-time portfolios that buy stocks of strategic exporters and sell non-strategic exporters. Portfolios are rebalanced monthly, and stocks are held for one month. The first row of each panel presents excess returns (raw returns minus the risk-free rate), the second row shows DGTW-adjusted returns, the third row shows CAPM alphas, the fourth row shows Fama-French 3-factor alphas, and the fifth row shows Carhart 4factor alphas. In Panel B, we replicate the calendar time portfolio approach from Panel A for our imports sample. $t$-stats are reported below coefficient estimates. ${ }^{*},{ }^{* *}$, and ${ }^{* * *}$ indicate statistical significance at the $10 \%, 5 \%$, and $1 \%$ levels, respectively.

\begin{tabular}{|c|c|c|c|}
\hline \multicolumn{4}{|c|}{ Panel A: Export Value-Weight Portfolio Returns } \\
\hline & Long Return & Short Return & (L-S) Return \\
\hline Excess returns & $\begin{array}{l}0.92^{\text {*** }} \\
(3.07)\end{array}$ & $\begin{array}{l}0.42 \\
(1.38)\end{array}$ & $\begin{array}{l}0.50^{* *} \\
(2.15)\end{array}$ \\
\hline DGTW-adjusted returns & $\begin{array}{l}0.28 \\
(1.52)\end{array}$ & $\begin{array}{l}-0.11 \\
(1.16)\end{array}$ & $\begin{array}{l}0.39^{* *} \\
(2.23)\end{array}$ \\
\hline CAPM alpha & $\begin{array}{l}0.62^{* * *} \\
(2.72)\end{array}$ & $\begin{array}{l}-0.02 \\
(0.19)\end{array}$ & $\begin{array}{l}0.64^{* * *} \\
(2.93)\end{array}$ \\
\hline Fama-French 3-factor alpha & $\begin{array}{l}0.64^{* * *} \\
(3.30)\end{array}$ & $\begin{array}{l}-0.02 \\
(0.24)\end{array}$ & $\begin{array}{l}0.66^{* * *} \\
(3.18)\end{array}$ \\
\hline Carhart 4-factor alpha & $\begin{array}{l}0.53^{* * *} \\
(2.82)\end{array}$ & $\begin{array}{l}-0.04 \\
(0.41)\end{array}$ & $\begin{array}{l}0.57^{* * *} \\
(2.78)\end{array}$ \\
\hline
\end{tabular}


Table VII: Portfolio Returns to Strategic Trading Activity (continued)

\begin{tabular}{|c|c|c|c|}
\hline \multicolumn{4}{|c|}{ Panel B: Import Value-Weight Portfolio Returns } \\
\hline & Long Return & Short Return & (L-S) Return \\
\hline Excess returns & $\begin{array}{l}0.87^{* *} \\
(2.31)\end{array}$ & $\begin{array}{l}0.42 \\
(1.38)\end{array}$ & $\begin{array}{l}0.45^{*} \\
(1.75)\end{array}$ \\
\hline DGTW-adjusted returns & $\begin{array}{l}0.34 \\
(1.52)\end{array}$ & $\begin{array}{l}-0.11 \\
(1.36)\end{array}$ & $\begin{array}{l}0.45^{*} \\
(1.92)\end{array}$ \\
\hline CAPM alpha & $\begin{array}{l}0.43^{*} \\
(1.75)\end{array}$ & $\begin{array}{l}-0.02 \\
(0.15)\end{array}$ & $\begin{array}{l}0.44^{*} \\
(1.71)\end{array}$ \\
\hline Fama-French 3-factor alpha & $\begin{array}{l}0.43^{*} \\
(1.74)\end{array}$ & $\begin{array}{l}-0.01 \\
(0.06)\end{array}$ & $\begin{array}{l}0.44^{*} \\
(1.68)\end{array}$ \\
\hline Carhart 4-factor alpha & $\begin{array}{l}0.37 \\
(1.48)\end{array}$ & $\begin{array}{l}-0.01 \\
(0.11)\end{array}$ & $\begin{array}{l}0.38 \\
(1.45)\end{array}$ \\
\hline
\end{tabular}




\section{Table VIII: Connected Board Members and Returns}

This table reports predictive regressions of future month returns on connectedness of a firm's board from 1999-2010. The independent variable of interest is Pct of Board Strategically Connected, which is equal to the percentage of the board of directors that are from a foreign country to which the firm is either importing from, or exporting to, in the month prior. Other control variables include Size, the natural logarithm of market capitalization, B/M, the natural logarithm of the ratio of book value to market value, Past Month Returns, returns in the month prior to the earnings announcement, and Past Returns (t-2,t-12), return from month t-2 to t- 12 . In Columns 1 and 2, the full sample of firms are included, while Columns 3 and 4 are run on only the sample of firms that have at least one strategically connected board member. Month fixed effects and Industry-Month fixed effects are included where indicated. t-stats, adjusting for clustering at the month level, are reported in parentheses. *, **, and *** indicate statistical significance at the $10 \%, 5 \%$, and $1 \%$ levels, respectively.

\begin{tabular}{|c|c|c|c|c|}
\hline \multirow{3}{*}{$\begin{array}{l}\text { Dependent Variable: } \\
\text { Sample: }\end{array}$} & \multicolumn{4}{|c|}{ Future-month returns } \\
\hline & \multicolumn{2}{|c|}{ Full Sample } & \multicolumn{2}{|c|}{$\begin{array}{l}\text { Only if have at least one } \\
\text { connected board member }\end{array}$} \\
\hline & $(1)$ & $(2)$ & $(3)$ & (4) \\
\hline $\begin{array}{l}\text { Pct of Board Strategically } \\
\text { Connected }\end{array}$ & $\begin{array}{l}0.082^{* *} \\
(2.41)\end{array}$ & $\begin{array}{l}0.091^{* * *} \\
(2.80)\end{array}$ & $\begin{array}{l}0.075^{* *} \\
(2.10)\end{array}$ & $\begin{array}{l}0.077^{* *} \\
(2.13)\end{array}$ \\
\hline Board Size & $\begin{array}{l}0.000 \\
(0.66)\end{array}$ & $\begin{array}{l}0.000 \\
(1.08)\end{array}$ & $\begin{array}{l}0.000 \\
(0.57)\end{array}$ & $\begin{array}{l}0.000 \\
(0.37)\end{array}$ \\
\hline Size & $\begin{array}{l}-0.002^{* * *} \\
(2.81)\end{array}$ & $\begin{array}{l}-0.002^{* * *} \\
(2.67)\end{array}$ & $\begin{array}{l}-0.003^{* * *} \\
(2.96)\end{array}$ & $\begin{array}{l}-0.002^{* * *} \\
(2.68)\end{array}$ \\
\hline $\mathrm{B} / \mathrm{M}$ & $\begin{array}{l}0.011^{*} \\
(1.87)\end{array}$ & $\begin{array}{l}0.011^{*} \\
(1.80)\end{array}$ & $\begin{array}{l}0.012 \\
(1.58)\end{array}$ & $\begin{array}{l}0.011 \\
(1.36)\end{array}$ \\
\hline Past Ret(t-2,t-12) & $\begin{array}{c}-0.002 \\
(0.59)\end{array}$ & $\begin{array}{l}-0.002 \\
(0.54)\end{array}$ & $\begin{array}{l}-0.001 \\
(0.18)\end{array}$ & $\begin{array}{c}-0.001 \\
(0.18)\end{array}$ \\
\hline Past Month Returns & $\begin{array}{l}-0.034^{* *} \\
(2.33)\end{array}$ & $\begin{array}{l}-0.032^{* *} \\
(2.27)\end{array}$ & $\begin{array}{l}-0.026 \\
(1.33)\end{array}$ & $\begin{array}{l}-0.027 \\
(1.48)\end{array}$ \\
\hline Time Fixed Effects & Yes & & Yes & \\
\hline Industry x Time Fixed Effects & & Yes & & Yes \\
\hline Adjusted $\mathrm{R}^{2}$ & 0.23 & 0.28 & 0.26 & 0.36 \\
\hline No. of Obs. & 38,040 & 38,040 & 11,039 & 11,039 \\
\hline
\end{tabular}




\section{Table IX: Errors in Analyst Forecasts and Earnings Surprises}

This table reports regressions of earnings forecast error and earnings surprise cumulative abnormal returns (CARs) on strategic trading of firms. In the first two columns, the dependent variable is Earnings CAR. This is defined as the cumulative abnormal return $(t-1, t+1)$ around the earnings date. The dependent variable in Column 3 and Column 4 is earnings Forecast Error. This is the absolute value of the actual reported earnings (EPS) value minus the consensus mean of the most recent analyst forecasts (in the month leading up to the announcement), scaled by the absolute value of actual EPS reported. This is then winsorized at the 0.01 level. The main variables of interest, Strategic Exporter/Importer, are defined in Table VI. Other control variables include Size, the natural logarithm of market capitalization, B/M, the natural logarithm of the ratio of book value to market value, Past Month Returns, returns in the month prior to the earnings announcement, Past Returns (t-2,t-12), return from month t-2 to t-12, and (Actual EPS-Estimate), which is the magnitude of the earnings surprise in the earnings announcement. Month and industry fixed effects are included where indicated. t-stats, adjusting for clustering at the month level, are reported in parentheses. *,**, and *** indicate statistical significance at the $10 \%, 5 \%$, and $1 \%$ levels, respectively.

\begin{tabular}{|c|c|c|c|c|c|c|c|c|}
\hline & \multicolumn{2}{|c|}{ Earnings CAR } & \multicolumn{2}{|c|}{ Forecast Error } & \multicolumn{2}{|c|}{ Earnings CAR } & \multicolumn{2}{|c|}{ Forecast Error } \\
\hline & (1) & $(2)$ & $(3)$ & $(4)$ & $(5)$ & $(6)$ & $(7)$ & $(8)$ \\
\hline Strategic Exporter & $\begin{array}{l}0.487^{*} \\
(1.90)\end{array}$ & $\begin{array}{l}0.577^{* *} \\
(2.24)\end{array}$ & $\begin{array}{l}2.861^{* *} \\
(2.48)\end{array}$ & $\begin{array}{l}2.874^{* *} \\
(2.53)\end{array}$ & & & & \\
\hline Non-Strategic Exporter & $\begin{array}{l}0.046 \\
(0.36)\end{array}$ & $\begin{array}{l}0.063 \\
(0.50)\end{array}$ & $\begin{array}{l}0.414 \\
(0.78)\end{array}$ & $\begin{array}{l}0.233 \\
(0.43)\end{array}$ & & & & \\
\hline Strategic Importer & & & & & $\begin{array}{l}0.634^{* *} \\
(2.58)\end{array}$ & $\begin{array}{l}0.665^{* * * *} \\
(2.66)\end{array}$ & $\begin{array}{l}3.880^{* * * *} \\
(2.66)\end{array}$ & $\begin{array}{l}3.886^{* * * *} \\
(2.64)\end{array}$ \\
\hline Non-Strategic Importer & & & & & $\begin{array}{c}-0.046 \\
(0.41)\end{array}$ & $\begin{array}{l}-0.03 \\
(0.27)\end{array}$ & $\begin{array}{l}-1.034^{*} \\
(1.86)\end{array}$ & $\begin{array}{l}-1.357^{* *} \\
(2.42)\end{array}$ \\
\hline Past Month Returns & $\begin{array}{l}-0.93 \\
(1.15)\end{array}$ & $\begin{array}{l}-0.914 \\
(1.13)\end{array}$ & $\begin{array}{c}-3.544 \\
(0.91)\end{array}$ & $\begin{array}{l}-3.841 \\
(0.99)\end{array}$ & $\begin{array}{l}-1.114 \\
(1.40)\end{array}$ & $\begin{array}{l}-1.131 \\
(1.41)\end{array}$ & $\begin{array}{l}-2.138 \\
(0.65)\end{array}$ & $\begin{array}{c}-2.036 \\
(0.62)\end{array}$ \\
\hline Size & $\begin{array}{l}-0.083^{* *} \\
(2.04)\end{array}$ & $\begin{array}{l}-0.072^{*} \\
(1.77)\end{array}$ & $\begin{array}{l}-3.693^{* * *} \\
(18.10)\end{array}$ & $\begin{array}{l}-3.678^{* * *} \\
(17.92)\end{array}$ & $\begin{array}{l}-0.099^{* *} \\
(2.50)\end{array}$ & $\begin{array}{l}-0.090^{* *} \\
(2.25)\end{array}$ & $\begin{array}{l}-3.935^{* * *} \\
(23.12)\end{array}$ & $\begin{array}{l}-3.981^{* * *} \\
(23.17)\end{array}$ \\
\hline $\mathrm{B} / \mathrm{M}$ & $\begin{array}{l}-0.072 \\
(0.60)\end{array}$ & $\begin{array}{l}-0.053 \\
(0.44)\end{array}$ & $\begin{array}{l}6.378^{* * *} \\
(14.41)\end{array}$ & $\begin{array}{l}6.327^{* * *} \\
(14.19)\end{array}$ & $\begin{array}{l}-0.137 \\
(1.31)\end{array}$ & $\begin{array}{l}-0.136 \\
(1.30)\end{array}$ & $\begin{array}{l}6.569^{* * * *} \\
(15.21)\end{array}$ & $\begin{array}{l}6.464^{* * *} \\
(14.78)\end{array}$ \\
\hline Past Ret $(\mathrm{t}-2, \mathrm{t}-12)$ & $\begin{array}{l}0.007 \\
(0.04)\end{array}$ & $\begin{array}{l}-0.007 \\
(0.05)\end{array}$ & $\begin{array}{l}-4.465^{* * *} \\
(3.78)\end{array}$ & $\begin{array}{l}-4.538^{* * *} \\
(3.78)\end{array}$ & $\begin{array}{l}-0.138 \\
(0.77)\end{array}$ & $\begin{array}{l}-0.14 \\
0.79)\end{array}$ & $\begin{array}{l}-4.519^{* * * *} \\
(5.39)\end{array}$ & $\begin{array}{l}-4.639^{* * *} \\
(5.46)\end{array}$ \\
\hline (Act EPS - Est) & $\begin{array}{l}3.594^{* * *} \\
(12.40)\end{array}$ & $\begin{array}{l}3.585^{* * *} \\
(12.43)\end{array}$ & & & $\begin{array}{l}4.189^{* * *} \\
(17.01)\end{array}$ & $\begin{array}{l}4.19^{* * *} \\
(16.97)\end{array}$ & & \\
\hline Time Fixed Effects & Yes & Yes & Yes & Yes & Yes & Yes & Yes & Yes \\
\hline Industry Fixed Effects & & Yes & & Yes & & Yes & & Yes \\
\hline Adjusted $\mathrm{R}^{2}$ & 0.08 & 0.08 & 0.11 & 0.11 & 0.07 & 0.07 & 0.11 & 0.11 \\
\hline No. of Obs. & 15,951 & 15,951 & 15,951 & 15,951 & 20,383 & 20,383 & 20,384 & 20,384 \\
\hline
\end{tabular}




\section{Table X: Segment Reporting and Connections}

This table presents coefficient estimates of fixed effects regressions of Segment Sales Ratio on Connected Population $(\mathrm{CP})$ and control variables: Segment Sales Ratio ${ }_{\text {ict }}=\mathrm{b} 1+\mathrm{b} 2 * \mathrm{CP}_{\mathrm{ct}}+\mathrm{b} 3 *$ Connected Board Member + Year Fixed Effect+ Country Fixed Effect.

Segment Sales Ratio is sales of a foreign segment scaled by total sales reported in all foreign segments in that year. Number of Firms in Country is the total number of firms reporting a segment sale in that country. Number of Countries is the total number of countries a firm reported in its segment files. If the reported segment is a country, Connected Population refers to the number of residents in a firm's headquarter MSA connected to a foreign country scaled by total population in that MSA $\left(\mathrm{CP}_{\mathrm{ct}}\right)$, and Connected Board Member takes the value of 1 if the firm has a board member who has an ethnicity tie to that country. If the reported segment is a region, Connected Population refers to the average of individual counties' connected population in a firm's headquarter MSA scaled by total population in that MSA, and Connected Board Member is the sum of connected board member values attached to each country in that region. T-stats, adjusting for clustering at the year level, are reported in parentheses. ${ }^{*},{ }^{* *}$, and ${ }^{* * *}$ indicate statistical significance at the $10 \%, 5 \%$, and $1 \%$ levels, respectively.

\begin{tabular}{lcc}
\hline & $\begin{array}{c}\text { Segment Sale } \\
\text { Ratio }\end{array}$ & $\begin{array}{c}\text { Segment Sale } \\
\text { Ratio }\end{array}$ \\
\cline { 2 - 3 } Connected Population & $0.05736^{* * *}$ & $0.0600^{* * *}$ \\
& $(4.14)$ & $(4.44)$ \\
Connected Board Member & & $0.0028^{* * *}$ \\
& & $(4.50)$ \\
Segment Sales & $0.0001^{* * *}$ & $0.0002^{* * *}$ \\
& $(4.77)$ & $(4.68)$ \\
Number of Firms in Country & & \\
& 0.0001 & 0.00003 \\
Number of Countries & $(0.54)$ & $(0.59)$ \\
& & \\
Year Fixed Effects & $-0.0054^{* * *}$ & $-0.0054^{* * *}$ \\
Country/Region Fixed Effects & $(18.20)$ & $(18.38)$ \\
Adj. R2 & & \\
Number of Observations & Yes & Yes \\
\hline
\end{tabular}




\section{Appendix: Supplementary Tables for "Resident Networks and Firm Trade"}




\section{Table A1: Summary Statistics on Firms that Do Not Import/Export}

This table provides summary statistics of publicly traded firms that do not engage in importing (or exporting). MVE is the market value of equity calculated as the price end of calendar year prior to fiscal year end multiplied by number of shares outstanding. $\mathrm{B} / \mathrm{M}$ is the book to market ratio where the book value of equity is calculated as sum of stockholders equity (SEQ), Deferred Tax (TXDB), Investment Tax Credit (ITCB) minus Preferred Stock (PREF). Leverage is longterm debt (DLTT) plus debt in current liabilities (DLC), divided by the numerator plus market equity. Past Return is the twelve month return prior to fiscal year end. ROA (return on asset) earnings before tax and depreciation (EBITDA) scaled by total assets (TA). PPE/TA is the ratio of plant, property, and equity (PPENT) scaled by total assets. The unit of observation is firmyear. Panel A (B) reports the summary statistics for public firms, which did not export (import) at all over the sample. The sample period covers 1994 to 2010.

Panel A: Firm level data for Non-Exporters

\begin{tabular}{lllllll}
\hline & MVE & B/M & Leverage & Past Return & ROA & PPE/TA \\
\hline mean & 1,896 & 16.515 & 0.216 & 0.172 & -0.011 & 0.271 \\
sd & 11,222 & $1,721.287$ & 0.215 & 1.084 & 1.646 & 0.277 \\
p5 & 3 & 0.063 & 0.000 & -0.694 & -0.536 & 0.003 \\
p10 & 7 & 0.132 & 0.000 & -0.547 & -0.255 & 0.010 \\
p25 & 24 & 0.301 & 0.018 & -0.265 & -0.005 & 0.039 \\
p50 & 108 & 0.579 & 0.163 & 0.039 & 0.071 & 0.161 \\
p75 & 555 & 0.974 & 0.352 & 0.363 & 0.141 & 0.448 \\
p90 & 2,569 & 1.605 & 0.527 & 0.844 & 0.213 & 0.741 \\
p95 & 6,854 & 2.339 & 0.639 & 1.364 & 0.270 & 0.840 \\
N & 144,330 & 144,330 & 167,639 & 106,365 & 161,877 & 163,223 \\
\hline
\end{tabular}

Panel B: Firm level data for Non-Importers

\begin{tabular}{lllllll}
\hline & MVE & B/M & Leverage & Past Return & ROA & PPE/TA \\
\hline mean & 1,824 & 16.929 & 0.218 & 0.170 & -0.012 & 0.273 \\
sd & 10,942 & $1,743.596$ & 0.216 & 1.084 & 1.665 & 0.278 \\
p5 & 3 & 0.061 & 0.000 & -0.694 & -0.541 & 0.002 \\
p10 & 6 & 0.130 & 0.000 & -0.547 & -0.259 & 0.010 \\
p25 & 23 & 0.301 & 0.019 & -0.265 & -0.006 & 0.039 \\
p50 & 102 & 0.581 & 0.165 & 0.038 & 0.071 & 0.164 \\
p75 & 521 & 0.980 & 0.354 & 0.361 & 0.141 & 0.454 \\
p90 & 2,418 & 1.617 & 0.530 & 0.838 & 0.214 & 0.745 \\
p95 & 6,523 & 2.353 & 0.641 & 1.357 & 0.271 & 0.843 \\
N & 140,660 & 140,660 & 163,974 & 102,780 & 158,211 & 159,547 \\
\hline
\end{tabular}


Table A2: Country-MSA Population Mapping

\begin{tabular}{|c|c|c|c|c|c|}
\hline & Country Name & $\begin{array}{l}\text { Population in } \\
\text { US }\end{array}$ & & Country Name & $\begin{array}{l}\text { Population in } \\
\text { US }\end{array}$ \\
\hline 1 & Argentina & Argentinian & 36 & Japan & Japanese \\
\hline 2 & Australia & White & 37 & Korea, Rep. & Korean \\
\hline 3 & Austria & White & 38 & Latvia & White \\
\hline 4 & Barbados & Mexican & 39 & Lithuania & White \\
\hline 5 & Belgium & White & 40 & Malaysia & Filipino \\
\hline 6 & Belize & Mexican & 41 & Malta & White \\
\hline 7 & Brazil & Mexican & 42 & Mexico & Mexican \\
\hline 8 & Bulgaria & White & 43 & Netherlands & White \\
\hline 9 & Cambodia & Filipino & 44 & New Zealand & White \\
\hline 10 & Canada & White & 45 & Nicaragua & Nicaraguan \\
\hline 11 & Chile & Chilean & 46 & Norway & White \\
\hline 12 & China & Chinese & 47 & Panama & Panamanian \\
\hline 13 & Colombia & Colombian & 48 & Paraguay & Paraguayan \\
\hline 14 & Costa Rica & Costa Rican & 49 & Peru & Peruvian \\
\hline 15 & Cuba & Cuban & 50 & Philippines & Filipino \\
\hline 16 & Czechoslovakia & White & 51 & Poland & White \\
\hline 17 & Denmark & White & 52 & Portugal & White \\
\hline 18 & Dominican Rep. & Dominican & 53 & Puerto Rico & Puerto Rican \\
\hline 19 & Ecuador & Ecuadorian & 54 & Romania & White \\
\hline 20 & El Salvador & Salvadorian & 55 & Russia & White \\
\hline 21 & Finland & White & 56 & Singapore & Chinese \\
\hline 22 & France & White & 57 & Spain & Mexican \\
\hline 23 & Germany & White & 58 & Sweden & White \\
\hline 24 & Greece & White & 59 & Switzerland & White \\
\hline 25 & Guatemala & Guatemalan & 60 & Taiwan, China & Chinese \\
\hline 26 & Haiti & Mexican & 61 & Thailand & Filipinos \\
\hline 27 & Honduras & Honduran & 62 & Turkey & White \\
\hline 28 & Hong Kong & Chinese & 63 & Ukraine & White \\
\hline 29 & Hungary & White & 64 & United Kingdom & White \\
\hline 30 & Iceland & White & 65 & Uruguay & Uruguayan \\
\hline 31 & India & Indian & 66 & Venezuela & Venezuelan \\
\hline 32 & Indonesia & Filipino & 67 & Vietnam & Vietnamese \\
\hline 33 & Ireland & White & 68 & Yugoslavia(FR) & White \\
\hline 34 & Israel & White & 69 & South Africa & White \\
\hline 35 & Italy & White & & & \\
\hline
\end{tabular}


Table A3: Country-Census Ethnicity Mapping

\begin{tabular}{|c|c|c|c|c|c|}
\hline & Country Name & Ethnicity & & Country Name & Ethnicity \\
\hline 1 & Argentina & HISPANIC & 36 & Japan & JAPANESE \\
\hline 2 & Australia & WHITE & 37 & Korea, Rep. & KOREAN \\
\hline 3 & Austria & WHITE & 38 & Latvia & WHITE \\
\hline 4 & Barbados & HISPANIC & 39 & Lithuania & WHITE \\
\hline 5 & Belgium & WHITE & 40 & Malaysia & FILIPINO \\
\hline 6 & Belize & HISPANIC & 41 & Malta & WHITE \\
\hline 7 & Brazil & HISPANIC & 42 & Mexico & HISPANIC \\
\hline 8 & Bulgaria & WHITE & 43 & Netherlands & WHITE \\
\hline 9 & Cambodia & FILIPINO & 44 & New Zealand & WHITE \\
\hline 10 & Canada & WHITE & 45 & Nicaragua & HISPANIC \\
\hline 11 & Chile & HISPANIC & 46 & Norway & WHITE \\
\hline 12 & China & CHINESE & 47 & Panama & HISPANIC \\
\hline 13 & Colombia & HISPANIC & 48 & Paraguay & HISPANIC \\
\hline 14 & Costa Rica & HISPANIC & 49 & Peru & HISPANIC \\
\hline 15 & Cuba & HISPANIC & 50 & Philippines & FILIPINO \\
\hline 16 & Czechoslovakia & WHITE & 51 & Poland & WHITE \\
\hline 17 & Denmark & WHITE & 52 & Portugal & WHITE \\
\hline 18 & Dominican Rep. & HISPANIC & 53 & Puerto Rico & HISPANIC \\
\hline 19 & Ecuador & HISPANIC & 54 & Romania & WHITE \\
\hline 20 & El Salvador & HISPANIC & 55 & Russia & WHITE \\
\hline 21 & Finland & WHITE & 56 & Singapore & CHINESE \\
\hline 22 & France & WHITE & 57 & Spain & HISPANIC \\
\hline 23 & Germany & WHITE & 58 & Sweden & WHITE \\
\hline 24 & Greece & WHITE & 59 & Switzerland & WHITE \\
\hline 25 & Guatemala & HISPANIC & 60 & Taiwan, China & CHINESE \\
\hline 26 & Haiti & HISPANIC & 61 & Thailand & FILIPINO \\
\hline 27 & Honduras & HISPANIC & 62 & Turkey & WHITE \\
\hline 28 & Hong Kong & CHINESE & 63 & Ukraine & WHITE \\
\hline 29 & Hungary & WHITE & 64 & United Kingdom & WHITE \\
\hline 30 & Iceland & WHITE & 65 & Uruguay & HISPANIC \\
\hline 31 & India & INDIAN & 66 & Venezuela & HISPANIC \\
\hline 32 & Indonesia & FILIPINO & 67 & Vietnam & VIETNAMESE \\
\hline 33 & Ireland & WHITE & 68 & Yugoslavia(FR) & WHITE \\
\hline 34 & Israel & WHITE & 69 & South Africa & WHITE \\
\hline 35 & Italy & WHITE & & & \\
\hline
\end{tabular}




\section{Table A4: State-level Connected Population}

Panel A of this table presents coefficient estimates of fixed effects regressions of export ratio (ER) on Connected Population $(\mathrm{CP})$ and control variables: $\mathrm{ER}_{\mathrm{ict}}=\mathrm{b} 1+\mathrm{b} 2^{*} \mathrm{CP}_{\mathrm{ct}}+\mathrm{b} 3 *$ Connected Board Member + Firm Fixed Effect + Year Fixed Effect + Ethnicity Fixed Effect + FirmxYear Fixed Effect. Export Ratio (ER) is total amount a given firm exports to a destination country in a given year scaled by total amount of exports of the same firm in the same year $\left(\mathrm{E}_{\mathrm{ict}} / \mathrm{Sum}\left(\mathrm{E}_{\mathrm{it}}\right)\right.$

). Connected population is the number of residents in firm's headquarter state connected to export country scaled by total population in that state $\left(\mathrm{CP}_{\mathrm{ct}}\right)$. Connected Board Member is a binary variable that takes a value of 1 if the firm has a board member with an ethnic background similar to export destination. Panel B of this table presents coefficient estimates of the following specification: $\mathrm{IR}_{\text {ict }}=\mathrm{b} 1+\mathrm{b} 2 * \mathrm{CP}_{\mathrm{ct}}+$ Firm Fixed Effect + Year Fixed Effect + Ethnicity Fixed Effect + FirmxYear Fixed Effect, where import ratio (IR) is total amount a given firm imports from a country in a given year scaled by total amount of imports of the same firm in the same year $\left(\mathrm{I}_{\mathrm{ict}} / \operatorname{Sum}\left(\mathrm{I}_{\mathrm{it}}\right)\right)$. T-stats, clustered by year, are reported below coefficient estimates. ${ }^{*},{ }^{* *}$, and *** indicate statistical significance at the $10 \%, 5 \%$, and $1 \%$ levels, respectively.

Panel A: Exports

\begin{tabular}{lllll}
\hline & Export Ratio & Export Ratio & Export Ratio & Export Ratio \\
\cline { 2 - 5 } Connected Population & $0.027^{* * *}$ & $0.025^{* *}$ & $0.313^{* * *}$ & $0.027^{* * *}$ \\
& $(2.70)$ & $(2.50)$ & $(5.13)$ & $(2.94)$ \\
Connected Board Member & & & \\
& & & & $0.012^{* * *}$ \\
& & & & $(3.31)$ \\
Firm Fixed Effects & Yes & No & No & No \\
Year Fixed Effects & Yes & No & No & No \\
FirmxYear Fixed Effects & No & Yes & No & Yes \\
Ethnicity Fixed Effects & Yes & Yes & Yes & Yes \\
StatexPartnerCountry Fixed Effects & No & No & Yes & No \\
& & & & 0.64 \\
Adj. R2 & 0.48 & 0.64 & 0.04 & 106,788 \\
Number of Observations & 106,788 & 106,788 & 106,788 & \\
\hline
\end{tabular}




\title{
Table A4: State-Level Connected Population (continued)
}

\author{
Panel B: Imports
}

\begin{tabular}{lllll}
\hline & Import Ratio & Import Ratio & Import Ratio & Import Ratio \\
\cline { 2 - 5 } Connected Population & $0.049^{* * *}$ & $0.058^{* * *}$ & $0.381^{* * *}$ & $0.061^{* * *}$ \\
& $(4.08)$ & $(4.46)$ & $(5.01)$ & $(4.85)$ \\
Connected Board Member & & & & $0.013^{* * *}$ \\
& & & & $(4.02)$ \\
& & & & No \\
Firm Fixed Effects & Yes & No & No & No \\
Year Fixed Effects & Yes & No & No & Yes \\
FirmxYear Fixed Effects & No & Yes & No & Yes \\
Ethnicity Fixed Effects & Yes & Yes & Yes & No \\
State x Partner Country Fixed Effects & No & No & Yes & \\
Adj. R2 & & & & 0.57 \\
Number of Observations & 0.39 & 0.57 & 0.06 & 103,829 \\
\hline
\end{tabular}

